\title{
32. PALYNOLOGY STUDIES OF SITES 336, 338, 345, 346, AND 348, DSDP LEG 38
}

\author{
E.V. Koreneva, E.D. Zaklinskaya, and G.M. Bratseva, Palynology Laboratories, \\ Geological Institute of the Academy of Sciences, USSR \\ and \\ G.G. Kartashova, Glaciology Section, Geography Department, Moscow State University, Moscow, USSR
}

\begin{abstract}
During DSDP Leg 38, unique sedimentary material was obtained from a series of sites in the Norwegian-Greenland Sea.

Sedimentary deposits overlying basalt are represented by a series of marine and subcontinental sediments of varied lithologic composition and thickness (from 100 to $800 \mathrm{~m}$ ). Basically these are clay, silt, sandy silt, biogenic oozes, and their lithified equivalents. The sediments contain abundant traces of marine microfauna and phytoplankton, as well as pollen and spores of terrestrial plants. The pollen and spores were studied by a group of palynologists from the laboratories of scientific research institutes in Moscow and Leningrad. The most detailed palynologic studies dealt with material from Sites 336, 338 and 345 . Other studies were also made on material from Sites 346 and 348.

Despite the relative incompleteness of the established complexes, the research not only the establishment and characterization of the sequence of development of flora from Paleogene to Pleistocene, but also curious regularities in the history of the formation of the spreading or opening of the Atlantic.
\end{abstract}

\section{INTRODUCTION}

The established floral proximity of the northeastern part of North America and the western part of Eurasia allowed Krutzsh $(1960,1962)$; Coczah et al. (1967); and Zaklinskaya (1970) to isolate the specific EuroAmerican paleofloristic kingdom "Norma," whose borders were successively preserved during the Late Cretaceous and early Paleogene. Identical stages and phases in the development of the "Norma" flora and the later flora which replaced it in the PaleogeneNeogene, as well as the identification of the taxonomic composition of its basic components naturally brought researchers to the conclusion that in the beginning of the Cenozoic, a single Euro-American continent existed, not one divided by an oceanic barrier.

The relationship between flora (on a generic and specific level) of the neo-Atlantic parts of North America and Eurasia in the Late Cretaceous and early Paleogene (Doyle, 1969; Manum, 1962; Zalinskaya, 1970) was also preserved in the later phases of the Cenophyte. A greater degree of relationship within the border of taxons of family and generic classes was also found. The Atlantic disengagement of the overwhelming majority of the natural habitats of the basic components of Euro-American flora had taken place by post-Eocene.

In light of the above, the significance can be properly evaluated by palynologic research on sedimentary sequences from deep holes including Pleistocene, Neogene, and Paleogene sediments. The lithologic composition of various horizons (sandy silt and clay containing terrigenous components) indicates the close proximity of a large part of sedimentary environments to the continent. Palynologic data, in conjunction with the very rich phytoplankton complex, indicate a repeated reoccurrence of transgressive movements of the oscillating newly forming Atlantic basin. Analysis of palynoflora shows a chronological sequence in the replacing of palynoflora which vary in taxonomic composition. It has also been established that Paleogene flora, corresponding to the time of formation of sediments of the marginal zone, are, to a significant degree, close to flora of the same age of the EuropeanTuranian paleoflora region.

\section{MATERIALS AND METHODS}

Samples from Sites 336, 338, 346, 345 and 348 were selected from a large number of cores as being the most promising in their content of pollen and spores. Samples, depending on their lithology and grain size, were subjected to: complex concentration by processing in $10 \% \mathrm{KOH}$ and $10 \% \mathrm{HCL}$, disintegration in a pyrophosphate solution $\left(\mathrm{NO}_{4} \mathrm{P}_{2} \mathrm{O}_{7}\right)$, separation in a heavy liquid $\left(\mathrm{CdF}_{2}=2.1-2.4\right)$, liberation from silicates with the help of cold $\mathrm{HF}$, and final processing with the aid of acetolise. From the prepared concentrate, glycerin suspension compounds were prepared in glycerin-gelatin. The collection of serial material, labeled by individual indexes, is preserved in the Department of Paleofloristics of the Geological Institute of the Academy of Sciences of the USSR under GIN No. 3948. 
The study was conducted with the help of light microscopes of the MBI-6, Microphoto D16 B and biological Ergaval systems, and was accompanied by mass micrographing under an oleaginous immersion with magnifications of $7 \times 60,7 \times 90,10 \times 60$, and 10 $\times 90$. The microphotograph scales are given in the plate figure captions. More than 100 samples have been studied and classified from sedimentary horizons, which contain sufficient pollen and spores.

Parallel with the palynological analysis, microphotography was conducted on particularly characteristic phytoplankton cells to confirm the established structure according to the pollen, as well as sediment character.

The stratigraphic designations of Neogene and Pleistocene are those of the shipboard paleontologists based on diatoms, Radiolaria, silicoflagellates, nannoplankton, and foraminifera. For the early Paleogene, the stratigraphic designations were defined on the basis of palynologic data, correlated with the help of characteristic key taxons established for western and central Europe and for the European part of the USSR (Kedves, 1967a, b, 1969, 1970, 1973; Korallova, 1973; Krutzsch, 1970, Portniagina, 1966, 1973; Mikhelis, 1973; Roche, 1970, 1973). Determination of the systematic membership of the pollen and spores was accomplished with the help of atlases, and the monographic descriptions of Krutzsh, 1967, 1970; Zaklinskaya, 1957, 1963; and Mchedlishvili, 1961; and Kupzianova, 1965. The location of the samples studied is given in Figure 1.

\section{DISCUSSION}

The majority of sedimentary sequences studied are characterized by a significant taxonomic variety of phytoplankton cells, spore-pollen coatings, which are characteristic of sediments of oceanic marginal zones. Together with the degree of pollen-bearing and variety of the taxonomic composition of the palynologic complexes, microplankton were studied to define the depositional facies of the sediment, and consequently, the specifics of paleogeography within the boundaries of the oscillating basin.

A definite relationship is observed between the degree of saturation of the palynocomplexes by pollen of Angiospermae, air-transported pollen of Gymnospermae, which have air sacs, microphytoplankton cells, and the lithologic and grain size composition of the sediment. The dependence can be represented as follows:

1) A sedimentary environment on the order of tens and a hundred meters from the shoreline is distinguished by an abundance or absolute dominance in the complexes of pollen of Angiospermae plants, which is combined with a significantly lower diversity and less abundant content of phytoplankton cells. There is also a significant coarsening of the sediment, often with the appearance of carbonaceous detritus. In the case of an estuary or delta conditions, cells of Azolla, or various types of Pediastrum are found in the palynological complexes.

Sediments of this category are representative of the basal part of the sections partially in late Oligocene strata. These sediments are characteristic at Site 336 $(349-444.0 \mathrm{~m})$, Site $338(285-405.5 \mathrm{~m})$, and Site 346 $(159-187 \mathrm{~m})$.

2) In a sedimentary environment within the first tens of kilometers from the shoreline, there is a considerable increase in complexes of coniferales pollen supplied by air transport. Correspondingly, the qualitative amount of (Angiosperm) pollen is decreased, and the cell composition of phytoplankton is changed. This regularly combines with a significantly decreased admixture of coarse-grain material, and a decrease in the mixture of terrigenous material.

The sediments are characteristic for the middle Oligocene, and, partly of the Miocene. They are also present in the basal part of Site 348 at a depth of 446522 meters (late Eocene/early Oligocene).

3) Sediments formed in environments the greatest distance from the shore boundaries (within the limits of the first hundreds of kilometers) are usually deprived of a sand fraction. In the palynocomplexes, either coniferales pollen supplied by air transport absolutely dominates, or the composition of sporadic pollen and spores is so random and incomplete that it is not possible to make conclusions or deductions. The complex of phytoplankton cells and spore-pollen casings is significantly poorer and, apparently, its significance in these conditions is significantly lowered.

The sediments are basically found in the highest horizons of the sections (Site 346, 44.5-110 m; Site 348, 37.5-284.5 m; Site 338, 76-161 m; and Site 345, 55-74 $\mathrm{m})$. According to ages based on diatoms and radiolarians, the sediments are Miocene and younger. These ages are correlated with ages obtained from palynological data.

As noted earlier, flora established on the basis of palynological data, for the most part, is close to the European-Turanian paleofloristic region. The late Paleogene and early Neogene stage was enriched by an Arcto-Tertiary element (so-called "Turgay complex"), characteristic primarily of forest landscapes of moderately warm latitudes of the Holarctic, in which there were abundant (up to the early Miocene) and variously represented conifers and angiosperms. Among the latter representatives are dominant types known among contemporary flora of the northern hemisphere.

Early Paleogene flora included a significant number of taxa of a subtropic root, and also a series of relics from the first faunas of the third stage of the Cenophyte (Danian-Paleocene), related to now extinct Amgiospermae taxons, whose pollen is classified in formal systematics.

At Sites 348 (346-522 m), $346(110-187 \mathrm{~m}), 336$ (339 $\mathrm{m}$ and $349-344 \mathrm{~m})$, and $338(285-408 \mathrm{~m})$, the palynoflora is represented basically by the following: Leiotriletes $\mathrm{sp}$., Leiotriletes adriensis W. Kr., Leiotriletes triangulis (Mur. et Pfl.) W. Kr., Leiotriletes paramaximums W. Kr., Stereisporites sp. (3 sp.), Triplanosporites sinuosus Th. et. Pfl., Triplanosporites sp., Reticulatisporites sp., Reticulatisporites verrucatus W. Kr., Retitriletes sp., Retitriletes pseudooculatus W. $\mathrm{Kr}$., Baculatisporites gemmatus W. Kr., Baculatisporites nanus W. Kr., Camarozonotriletes minoris W. Kr., 

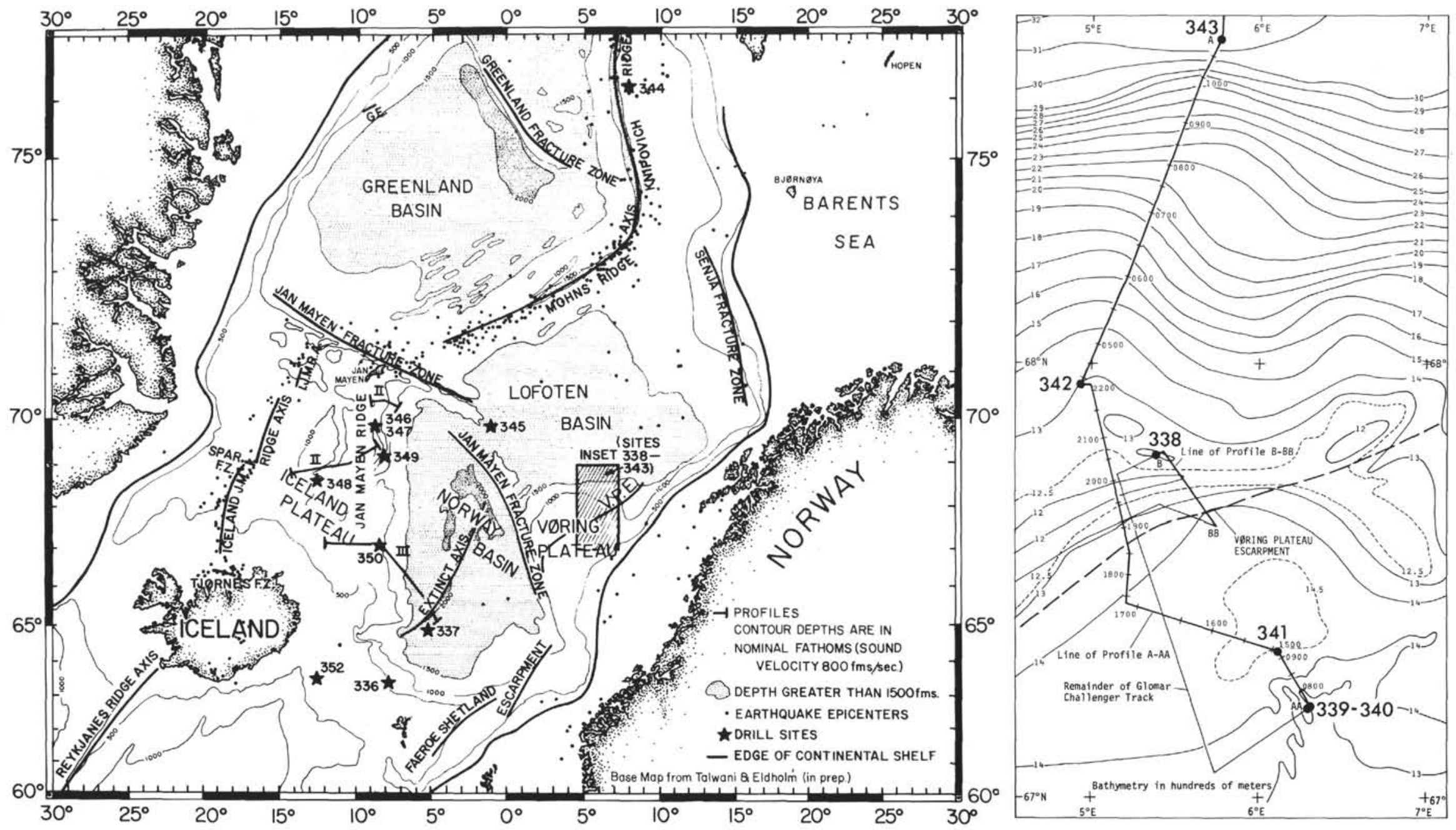

Figure 1. Location of Leg 38 drilling sites, and bathymetry and structure of the Norwegian-Greenland Sea. (Note: Site 351 was occupied but was not drilled. Its location has not been shown on this map. The inset map shows the track of Glomar Challenger between Sites 338 and 343 on the Voring Plateau. Portion between Sites 339 and 343 corresponds to line of composite profile illustrated in accompanying diagram. Also shown are position of Voring Plateau Escarpment, and corrected bathymetry of the area, in hundreds of meters, constructed principally from records taken by $R / V$ Vema of Lamont Doherty Geological Observatory, supplemented by Glomar Challenger data. 
Gleicheniidites sp., Gleicheniidites toriconcavus W. Kr., Verrucatosporites sp., Neogenispori sp., Intrapunctisporites gracilis W. Kr., Concavisporites sp., Lusasporis sp., Osmundacites sp., Pittyosporites Seward (3 sp.), Pittyosporites alatus (R. Po) Dacrydium sp., Podocarpus sp. (2 sp.), Sequoia sp., Sciadopytis sp., Keteeleria sp. (2 sp.) Piceites sp., Picea sect. Omorica, Pinus sp. (4 sp.), Pinus sect. Taedae, Pinus bancsiannaeformis Zakl., Pinus sect. Cembrae, Pinus protocembra Zakl., Pinus aff. koraiensis., Pinus singularis Zakl., Cedrus sp., Cedrus laxiretticulata Zakl., Cedrus janschinii Zakl. Abietinaepollenites sp., Abies sp., Interpollis supplingensis W. Kr. (Anacolosidites supplingensis), Trudopollis pertrudens Pfl., Interporopollenites sp., Vacuopollis semiconcavus Pfl., Sporopollis sp., Sporopollis singularis Zakl., Complexiopollis sp., Tenerina sp., Plicatopollenites lunatus W. Kr., Triatriopollenites rurensis $\mathrm{Pfl}$, Triatriopollenites aroboratus Pfl., Triatriopollenites sp., Triporopollenites giganteus Pfl., Triporopollenites palaeobetaloides W. $\mathrm{Kr}$., Intratriporopollenites microinstructus $\mathrm{W}$. Kr. et Roche, Pentapollenites laevigatus W. Kr., Tetrapollis sp., Tricopopollenites $\mathrm{sp}$. (2 sp.), Tricolporopollenites $\mathrm{sp}$. (2 sp.), Trivestibulopollenites betuloides Pfl., Plicatopollis sp. (3 sp.), Alnipollenites verus R. Pot., Myricites Krempii W. Kr., Myrica sp., Betula sp., Alnus sp. (2 sp.), Plicatopollis carpinoides, Engelhardtia sp., Carya sp., Platycarya sp., Ulmoideipites krempii Anderson, Ulmus sp., Celtis sp., Ericaceae (gen. et sp.), Araliaceae (gen. et sp.), Caryapollenites simplex ( $\mathrm{r}$. Pot.), Revesioepollenites sp., Aquilapollenites subtilis Samoil., Triprojectus.

The most characteristic types of pollen and spores are depicted on Plates 1 through 9.

It is necessary here to note that the present report must be viewed as preliminary. Further study of the materials from Leg 38 will be continued, and correspondingly, the lists of fossils will be enlarged, and interpretation of the data will be made more precise.

However, the analysis of even this preliminary data shows almost identical floristic lists of palynocomplexes, and in characteristic taxons in these lists, with the composition of characteristic taxons known from classic locations of the so-called "Gelindenian" flora of Belgium (Roche, 1973), the Paris basin and the Hungarian lowland (Kedves, 1974), and central and western Europe (Korallova, 1973). Although there is a type of "incompleteness" of palynoflora obtained from the Leg 38 samples, it is possible, at the same time, to note established characteristic, correlative and key taxons: Alnipollenites verus, Complexiopollis, Pentapollenites la evigatus, Trudopollis, Sporopollis singularis, Interpollis supplingensis, Oculopollis, Plicatopollis, and Vacuopollis. These forms, as well as many others, allow the conclusion for an indisputable Eocene age of the sediments. Moreover, the basal section of the holes is represented by the final phases of the Eocene, or frontier horizons between the middle and upper Eocene.

Palynoflora from the middle portions of Sites 346, $336,338,345$ and 348 are significantly richer in types of gymnospermae pollen (gymnosperms) the majority of which are identical to Oligocene flora of the EuropeanTuranian region. The palynocomplexes include: Pinus sect Australes, Pinus protocembrae, Pinus sect. Taeda, Cedrus janschini, Abies, Picea, Picea sect. Eupiceae, Picea sect. Omorica. These are characteristic, from the late Eocene-early Oligocene, of the south of Western Siberia, Turgay, north Kazakhstan, and northern PreAral. Several types of Tsuga appear.

However, distinguished from the complexes of the Oligocene-early Miocene, among representatives of gymosperm, are an insignificant number of representatives of types, whose natural habitats in their contemporary form, are linked with the southern hemisphere (Podocarpus, Dacrydium).

In the composition of angiosperm pollen, there is constant participation of the following representatives: Yglans, Carya, Pterocarya, Engelhardtia, Quercus, Fagus, Alnus, Betula, Myrica, Tilia, Liquidambar, and Ulmus. All of these types, with the exception of Tilia and Liquidambar, are represented by several types of pollen. The spore complex usually contains: Leiotriletes adriensis, Stereiosporites, significant amounts of Lycopodiales and Osmundaceae, and also Polypodiaceae having spores of a bean-like form. Complexes from deposits dated as Oligocene and lower Miocene usually are almost entirely represented by gymnosperm pollen, in whose composition the amount of Taxodiaceae is significantly increased. Basically, this is a type, close to Taxodium distichum, which together with discoveries of the pollen Taxodium and Myrica and Nyssa (Site 336, 168.5-254.0 m), indicates a moist climate. At the same time, there is a significant impoverishment in the cell composition of planktonic algae, and a sharp decrease in their quantitative content. This can indirectly serve as an indicator of closeness to the shoreline, which favorably coincides with the dominance in palynocomplexes of the pollen Taxodiaceae, but not Pinaceae, whose pollen possesses a distinctly larger area of distribution. Complex from deposits dated as Miocene (upper part) usually are almost entirely represented by pollen Pinaceae (mainly Pinus). A similar combination is observed in the 176.0142.5 meter depth at Site 338, (late Oligocene, by diatoms).

Palynoflora of the highest horizons at Sites 341, 342, and 344 are dated as Neogene-lower Pleistocene, according to Maliaslova (personal communication), and are enriched with pollen of herbaceous plants of the families Compositae, Cyperaceae, Gramineae, Leguminosae, and Rosaceae. The flora includes a great number of redeposited forms of pollen and spores from the Mesozoic and Paleogene. The composition of pollen from wood pulp plants is extremely poor and includes Pinus, Picea, Alnus, Betula, and Salix. According to the data available, it is difficult to establish any kind of regularity in changes of the flora through the sediment sequence.

\section{CONCLUSIONS}

In comparing the established palynoflora from various stratigraphic levels in the holes with palynoflora of the closest sectors, known from marine and continental deposits revealed within the boundaries of contemporary continents, it is possible to come to the following conclusions (Figure 2). 


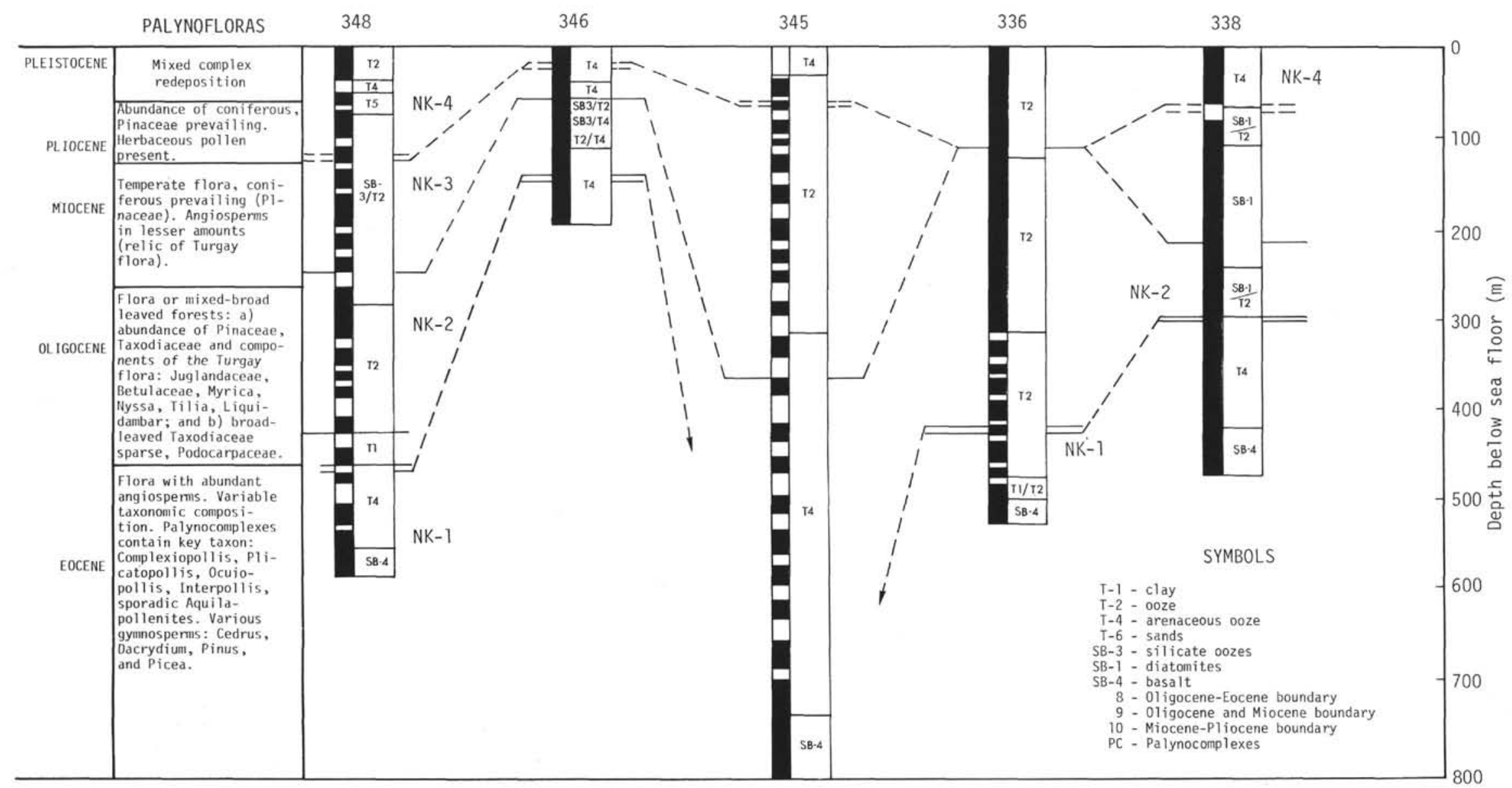

Figure 2. Palynological correlation for Sites 336, 338, 345, 346 and 348. 
1) At an early stage of formation of the deposits (end of the middle-late Eocene, perhaps the earliest phases of the Oligocene) terrestrial flora located in the coastal zones of the approaching sea were similar to the flora of the European-Turanian paleofloristic region, and in particular to its western and central provinces. The flora from classical locations have been well studied, and are well known in the literature. For the most part, the palynostratigraphic horizons correlate well with the zonal scale based on planktonic foraminifera.

These flora are, in essence, close to the Wilcox complex (Texas) studied by Krutzsh (1969). In age and evolutionary level, the Wilcox flora reveals a similarity to palynoflora established in the basal horizons of Sites 336 and 338 , and somewhat older palynoflora of the basal horizons at Site 348. Apparently the flora established, according to palynological data of the coastlines, represented the last phase of the third and the first phase of the fourth stages of the Cenophytic associated with the middle and late Eocene boundary when there occurred a significant re-formation of the vegetable cover within the boundaries of the entire northern hemisphere. This was particularly clearly reflected in the irreversible replacement and significant participation of the angiosperm flora. The angiosperm pollen is classified in the class "Norma," by the rule in the composition of all vegetable associations of angiosperm taxa already known in the contemporary flora of the earth.

2) Flora of the second stratigraphic level (Oligoceneearly Miocene) are absolutely identical with flora of the "Turgay type" known in various sites of the Oligocene and Miocene of western central Europe, the European part of the USSR. They are also comparable with palynoflora of the southern part of western Siberia, the Crimera-Caucasian region, Turgay, and north Kazakhstan. They are distinguished from it only by the complete absence of pollen of herbaceous plants.

Flora of this level can be subdivided into two complexes: (1) The late Oligocene-early Miocene complex characterized by abundance of Taxodiaceae, Pinaceae, and broad-leaved rocks. (2) The early-middle Oligocene complex. It abounds in various Pinaceae (Pinus, Tsuga, Picea, Abies), coniferous pollen of the southern hemisphere - Podocarpus and Dacrydium being present as well.

3) The combination of data from palynological analyses, qualitative indicators, such as the filling out and typological diversity of pollen of various groups of plants and cells of phytoplankton, and also the diversity in lithological composition of the sediments, allows one to establish an idea of the intensity and schedule of formation of oceanic drift between the continents of North America and Eurasia. In schematic approximation, it is possible to imagine that during the Eocene in the northern regions of the Atlantic, the shoreline of the continents was located relatively close to the site areas studied. This is indicated by the admixture of coarsegrained material in the deposits, and by the abundance and diversity in the composition of angiosperm pollen in the palynocomplexes, and relative poverty of the phytoplankton content. During the Oligocene, the tempo changed several times, and the "shallowing" of the basin can be compared with the time during the late Oligocene, when in the region of Site 336 , clay was deposited containing an abundance of Taxodum, and a varied complex of angiosperm pollen. However, as a whole, the Oligocene-Miocene stage apparently coincided with the active implementation of spreading; which is testified to by the predominantly rich and varied complex of planktonic flora, and the predominance (though not absolute) of gymnosperm pollen in the overwhelming majority of palynocomplexes for the entire section.

\section{ACKNOWLEDGMENTS}

In conclusion we consider it a pleasant duty to express our gratitude to both the American and Soviet researchers who organized the complex scientific treatment of the materials on Leg 38 and, particularly to Dr. G.B. Udintsev who provided exceptionally abundant and carefully selected material for palynology.

\section{REFERENCES}

Doyle, J., 1969. Cretaceous angiosperm pollen of the Atlantic coastal plain and its evolutionary significance: J. Arnold Arboretum, v. 50, p. 1-35.

Goczan, F., Croot, J., Krutzsch, W., Pacltova, B., 1967. Gattungen des "Stemma Normapolles Pflug" (Angiospermae): Paläonyol. Abh. B., v. 11, p. 1-540.

Kedves, M., 1967a. Etudes palynologiques de couches du tertiaire inferieur de la region Parisienne. Spores: Pollen et Spores, v. IX, p. 521-552.

1967b. Sur quelques problemes de stratigraphie palynologique appliquee au tertiaire inferieur en Europe: Pollen et spores, v. IX, p. 302-334.

Kedves, M., 1969. Etudes palinologiques des Couches du Tertiare inferior de la region Parisienns. IV, Pollenes des Normanollis: Pollen et Spores, v. XI, p. 386-396. 1970. Sur quelques problemes de stratigraphie palinologique appliquee en tertiaire inferieure en Europe: Pollen et Spores, v. IX, p. 322-334.

1973. Paleogene fossil sporomorphs of the Bakony Mountains, Part I: Studia Biologica Hungarica, v. 12: Budapest, (Academy of Sciences), Hungary, p. 1-34.

1974. Paleogene fossil Sporomorphs of the Baxony

Mountains Part II., Studia biologica Hungarica, 13: Acad. Krads, Budapest, p. 1-124.

Korallova, V. 1973, Spory i pyl'tsa nizhnego paleotsena severnoi chasti Prichernomorskoi vpadiny: Palinologiia kainofita, Trans. third Internat. Palin. Conf., Nauka, p. $52-55$.

Krutzsh, W., 1960. Uber Thomsonipollis magnificus (Th., Pf., 1953) n. gen., n. comb., und Bemerkungen Zurregionalen Verbreitung einiger dollen-Gruppen in alteren Palaogen: Freiburger Forsshungesh. Sonderdruch, H., C. 86 , Berlin, p. 54-56.

, 1967. Atlas der mittel und jungtertiären dispersen Sporen und Pollen sowieder Mikroplanctonformen der nördischen Nitteleuropas: Lieferung 4 und 5.

1969. Taxonomie syncolp(or) ater und morphologisch benachbarter pollengattungen und arten (sporae dispersae) aus der oberkreide und dem tertiaer. Teil L: Syncolp (or) ate und syncolp (or) atoide pollenformen: Pollen et Spores, v. XI, p. 398-424.

1970. Die stratigraphisch verwertbaren Sporen und Pollenformen des mitteleuropäischen Alttertiä, S. Ib: Geol. Bd. 2, fur 1967, 1. Abb. p. 209-379.

Kuprrianova, L., 1965. The palynology of the amentiferae: Komarov Botany Institute, Academy of Sciences, USSR, Mowcow and Leningrad, (Nauka), p. 1-215. 
Manum, S., 1962. Studies in the Tertiary flora of Spitsbergen, with notes on Tertiary floras of Ellesmer Island, Greenland and Iceland: Norsk Plarinstitutt Skrifter, p. 1111.

Mchedlishvili, N., 1961. Pyl'tsa dvudol'nykh, opredelennaia po istusstvennoi klassifikatsii tip. Projectoaperturites N. Mtchedl nadgruppa Triprojectacites N. Mtch: In Pyl'tsa i spory Zapadnoi Sibiri. Iura-paleotsen. Trudy VNIGRI, vyp. 177 (Leningrad), p. 203-230.

Mikhelis, A., 1973. Osnovnye zakonomernosti izmeneniia palinokompleksov paleogenovykh i neogenovykh otlozhenii Donbassa: In Palinologiia kainofita trans third Internat. Palin. Conf., Nauka, p. 117-127.

Portniagina, L., 1966. Osobennosti rannepaleogenovoi flory Karpat. Znachenie palinologicheskogo analiza flia stratigraffi. In Paleofloristiki: Moscow (Nauka), p. 158163.

1973. Stratigraphy and palynology of the Upper Cretaceous-Paleogene deposits of the Skiba zone of the Carpathians. The palynology of cenophytic: Mowcow and Leningrad (Nauka), p. 39-42.

Roche, E., 1970. Flores du Paleocene et de l'Eocene inferieur des basins sedimentaires anglais Belge et Parisien: Interets climatique et Phytogeographique. Assoc. Nat, des Professeurs de Biologie de Belgique, 16e Annee NM, 1970, p. 109-134.
1973. Etudes des sporomorphes du Landenien de Belgique et de quelques gesiments du sparnacien francais: Mem. expl. Carten Geologiques et Minerals de la Belgique, no. 13, p. 1-121.

Zaklinskaya, E., 1957. La valeur stratigraphique du pollen des gymnospertes des depots de la region de Pavlodar sur l'Irtych et du la region de la mer d'Aral: Trudy Inst Geol Akad Nauk SSSR 6, p. 1-184.

1960. On the role of angiosperm pollen in the stratigraphy of Upper Cretaceous and Paleogene period: Doki. Akad. Nauk SSSR 133, v 2, p. 431-434.

1962. Importance of angiosperm pollen for the stratigraphy of Upper cretaceous and lower Paleogene deposits and botanical-geographical provinces at the boundary between the Cretaceous and Tertiary systems: First Intern. Conf. Palyn. Akad. Nauk SSSR, p. 105-113. , 1963. Pyl'tsa pokrytosemennykh i ee znachenie dlia obosnovaniia stratigra verkhnego mela i paleogena: Trudy Geol. In-ta AN SSSR, v. 74. izd. AN SSSR, Moscow, p. 1-253.

1970. Pozdnemelovye i rannepaleogenovye flory (po palinologicheskim dannym). In Paleozoiskie $\mathrm{i}$ mezozoiskie flory Evrazii i fiteografiia etogo vremeni: Moscow (Nauka), p. 302-330. 


\section{PLATE 1}

(Magnification: all $\times 1000$ )

Figures 1, 2 Lycopodium sp. Site 348, Core 8-CC, Sample No. $350 \mathrm{k} / \mathrm{m}$, Collection No. 3948, Geological Institute of Academy of Sciences, USSR, Pliocene.

Figure 3 Polypodiaceae. Site 348, Sample 8-CC, Sample No. $350 \mathrm{k} / \mathrm{m}$, Collection No. 3948 , Geological Institute of Academy of Sciences, USSR, Pliocene.

Figure $4 \quad$ Pinus silvestris L. Site 348, Sample 5, CC, Sample No. $346 \mathrm{k} / \mathrm{m}$, Collection No. 3948, Geological Institute of Academy of Sciences, USSR, Pleistocene.

Figure 5

Picea sp. Site 348, Sample 8-CC, Sample No. 350 k/m, Collection No. 3948, Geological Institute of Academy of Sciences, USSR, Pliocene.

Figure 6 Tsuga sp. Site 348, Sample 8-CC, Sample No. 350 $\mathrm{k} / \mathrm{m}$, Collection No. 3948, Geological Institute of Academy of Sciences, USSR, Pliocene.

Figures 7,8 Ranunculaceae. Site 348, Sample 5, CC, Sample No. $346 \mathrm{k} / \mathrm{m}$, Collection No. 3948, Geological Institute of Academy of Sciences USSR, Pleistocene.

Figures 9, 10 Chenopodiaceae. Site 348, Sample 8, CC, Sample No. $350 \mathrm{k} / \mathrm{m}$, Geological Institute of Academy of Sciences USSR, Pliocene.

Figure 11 Betula sect. Albae. Site 348, Sample 8, CC, Sample No. $350 \mathrm{k} / \mathrm{m}$, Collection No. 3948 , Geological Institute of Academy of Sciences USSR, Pliocene.

Figure 12 Betula sect. Albae Site 348, Sample 4, CC, Sample No. $346 \mathrm{k} / \mathrm{m}$, Collection No. 3948, Geological Institute of Academy of Sciences, USSR, Pleistocene.

Figure 13 Betula sect. Nanae. Site 348, Sample 8, CC, Sample No. 350 k/m, Collection No. 3948, Geological Institute of Academy of Sciences USSR, Pliocene.

Figure 14 Betula sect. Nanae. Site 348, Sample 8, CC, Sample No. 350 k/m, Collection No. 3948, Geological Institute of Academy of Sciences USSR, Pliocene. 


\section{PLATE 1}

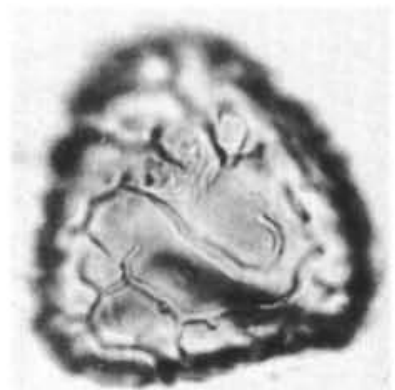

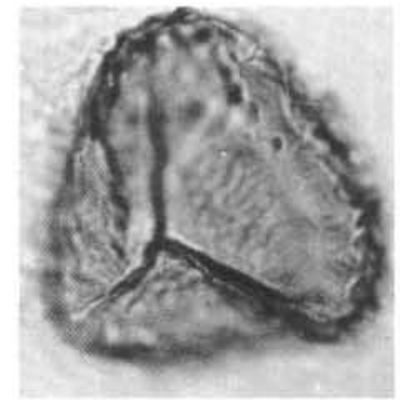

2

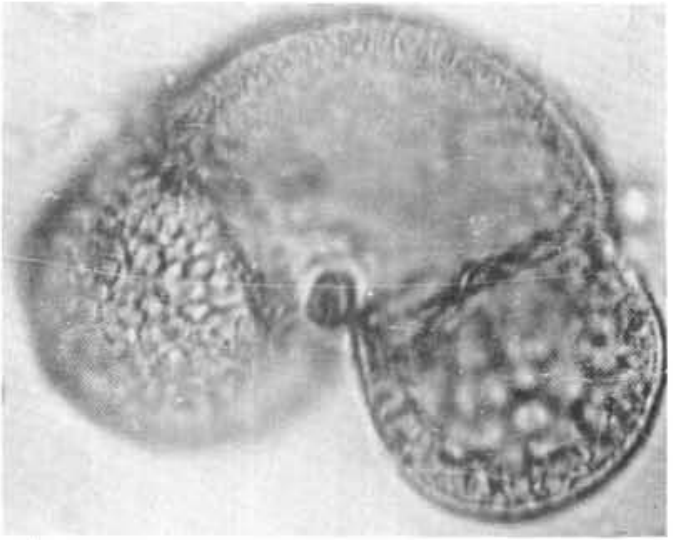

4

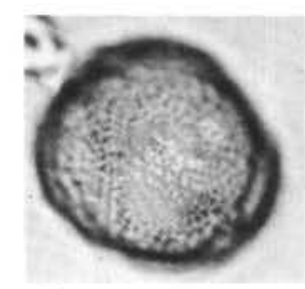

7

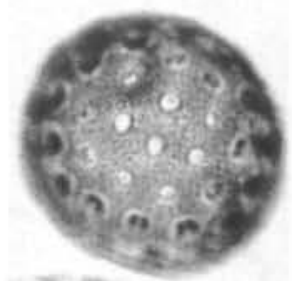

9

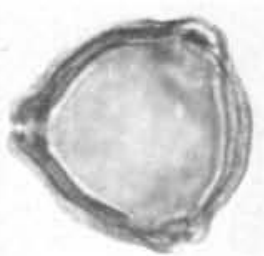

11
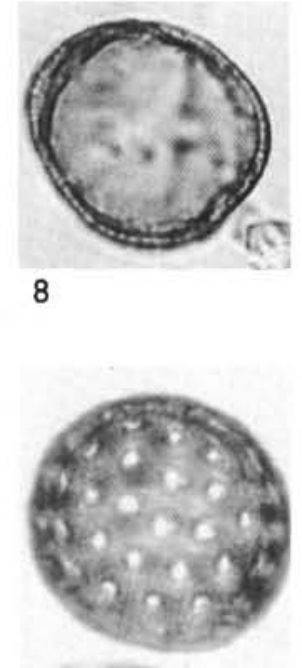

10

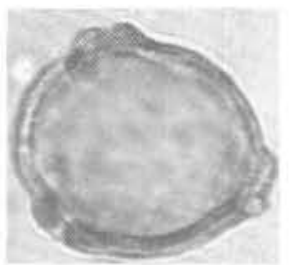

12

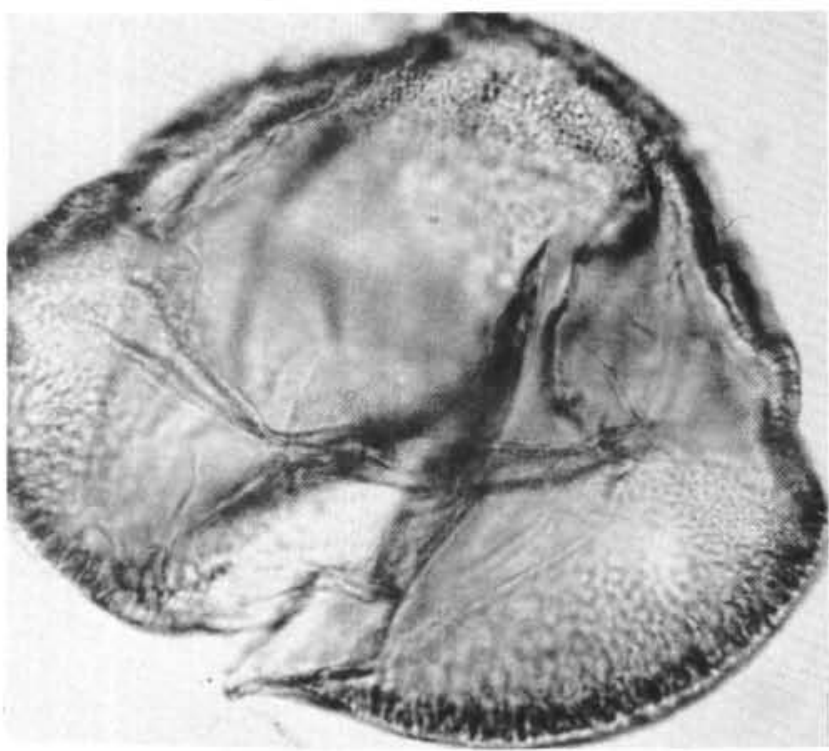

5

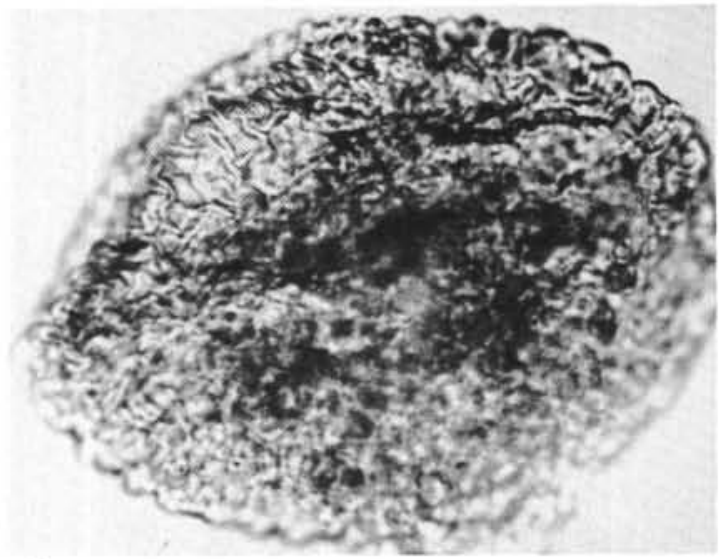

6

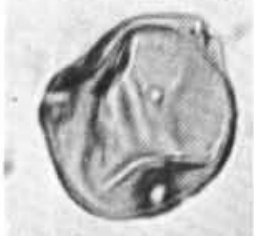

13

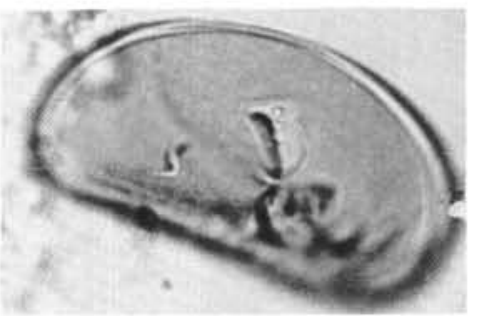

3 


\section{PLATE 2}

(Magnification: all $\times 1000$ )

Figures 1-3 Pteridium $\mathrm{sp}$. Site 338, Sample 8-3, 40-42 cm, Sample No. 380 k/m, Collection No. 3948, Geological Institute of Academy of Sciences USSR, Miocene.

Figure 4

Cyathea $s p$. Site 345, Sample 6-2, 118-120 cm, Sample No. $561 \mathrm{k} / \mathrm{m}$, Collection No. 3948, Geological Institute of Academy of Sciences, Miocene.

Figure 5 Osmunda $s p$. Site 338, Sample 8-3, 40-42 cm, Sample No. 380 k/m, Collection No. 3948, Geological Institute of Academy of Sciences USSR, Miocene.

Figure 6 Reticulatosporites (Lycopodium), Site 338, Sample 8-3, 40-42 cm, Sample No. $380 \mathrm{k} / \mathrm{m}$, Collection No. 3948, Geological Institute of Academy of Sciences USSR, Miocene.

Figure $7 \quad T$ suga sp. Site 348, Sample 11, CC, Sample No. $353 \mathrm{k} / \mathrm{m}$, Collection No. 3948, Geological Institute of Academy of Sciences USSR, Miocene.

Figure 8 Taxodium sp., Site 338, Sample 8-3, 40-42 cm, Sample No. $380 \mathrm{k} / \mathrm{m}$, Collection No. 3948, Geological Institute of Academy of Sciences, USSR, Miocene.

Figure 9 Taxodium $\mathrm{sp}$. Site 338, Sample 8-3, 40-42 cm, Sample No. 380 k/m, Collection No. 3948, Geological Institute of Academy of Sciences USSR, Miocene. 
PLATE 2

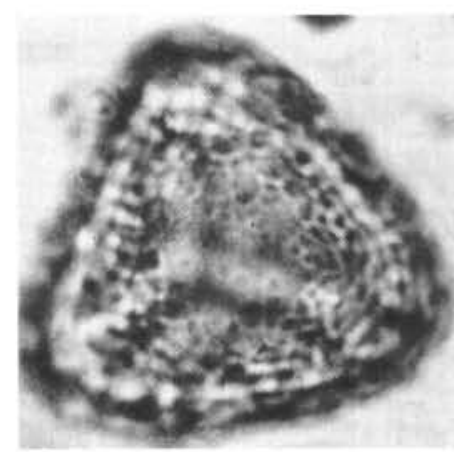

1

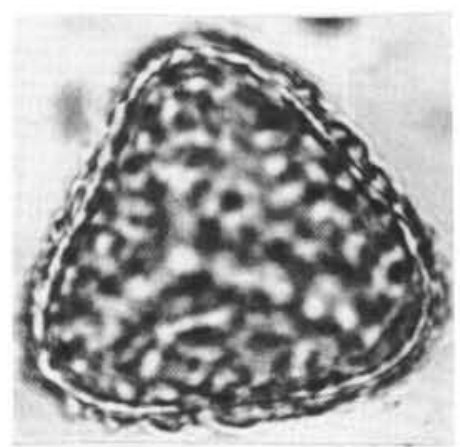

2

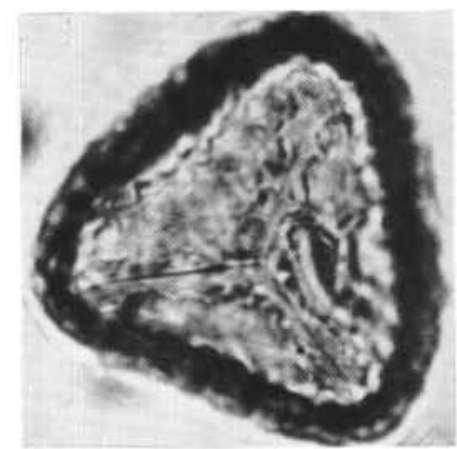

3

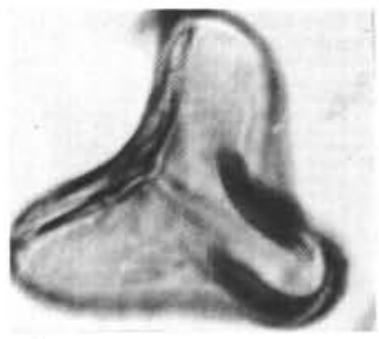

4

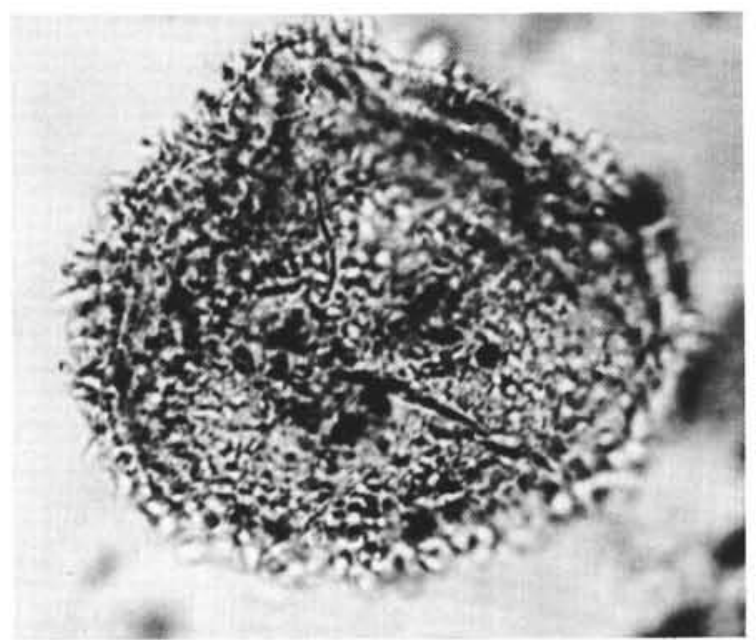

5

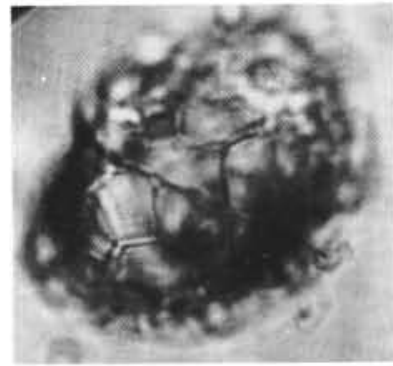

6
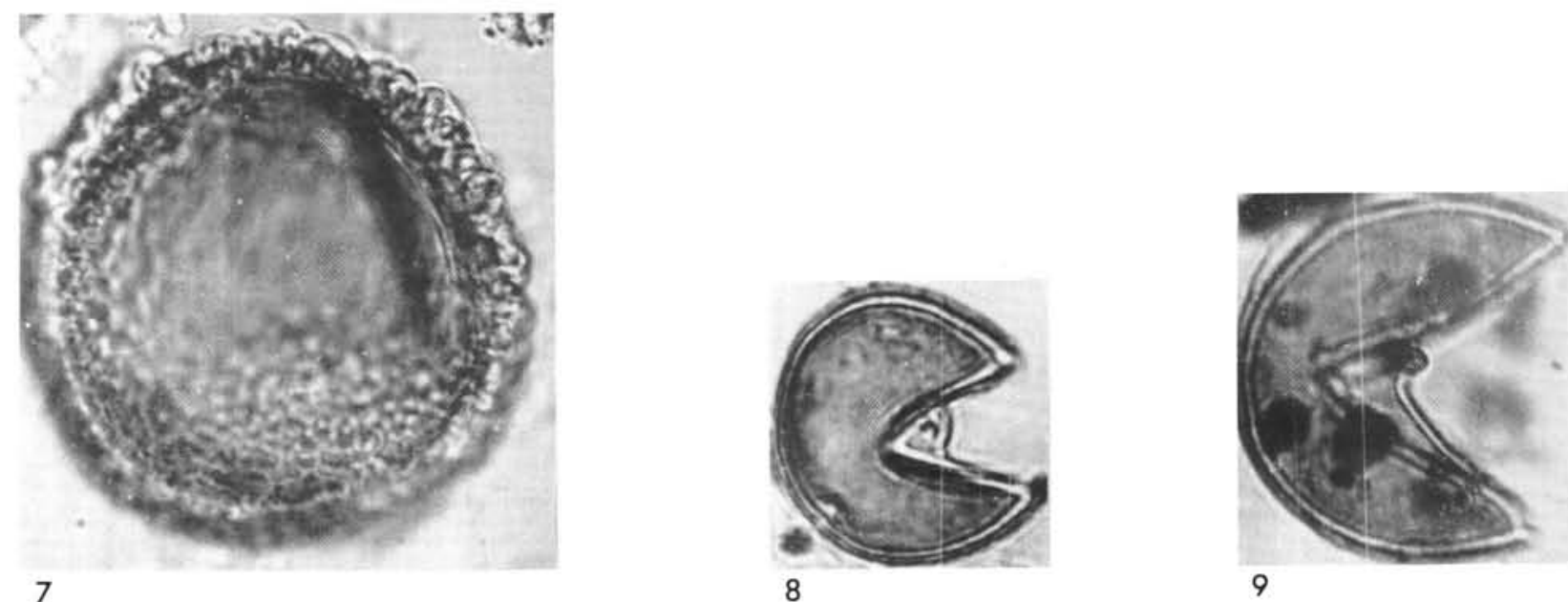


\section{PLATE 3}

(Magnification: all $\times 1000$ )

Figures 1, 2 Pinus sect. Cembrae. Site 345, Sample 6-2, 118-120 $\mathrm{cm}$, Sample No. $561 \mathrm{k} / \mathrm{m}$, Collection No. 3948, Geological Institute of Academy of Sciences USSR, Miocene.

Figure 3 Pinus sect. Eupitys. Site 338, Sample 8-3, 40-42 $\mathrm{cm}$, Sample No. $380 \mathrm{k} / \mathrm{m}$, Collection No. 3948, Geological Institute of Academy of Sciences USSR, Miocene.

Figure $4 \quad$ Pinus sp. Site 348, Sample 11, CC, Sample No. 353 $\mathrm{k} / \mathrm{m}$, Collection No. 3948, Geological Institute of Academy of Sciences USSR, Miocene.

Figure 5 Pinus sect. Cembrae. Site 348, Sample 11-CC, Sample No. $353 \mathrm{k} / \mathrm{m}$, Collection No. 3948, Geological Institute of Academy of Sciences USSR, Miocene.

Figure 6 Pinus sect. Eupitys. Site 348, Sample 12-CC, Sample No. $354 \mathrm{k} / \mathrm{m}$, Collection No. 3948, Geological Institute of Academy of Sciences USSR, Miocene. 
PLATE 3

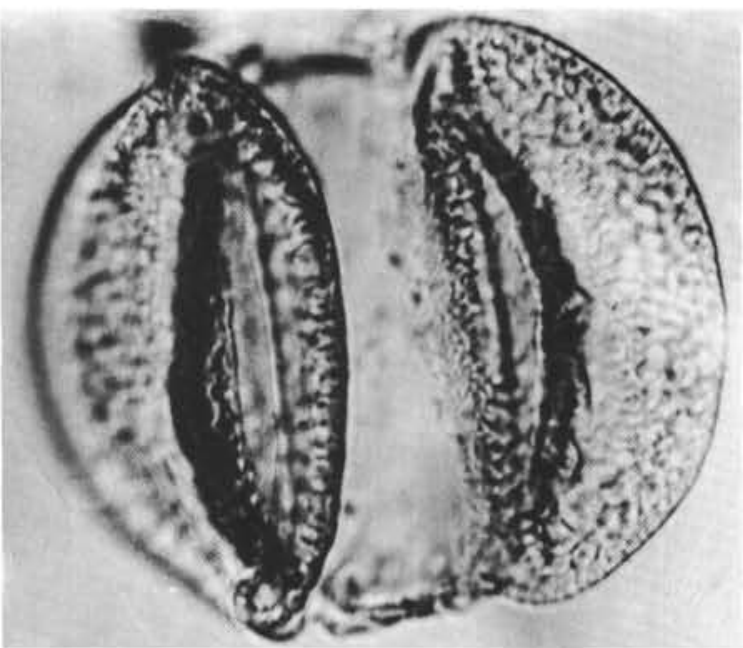

1

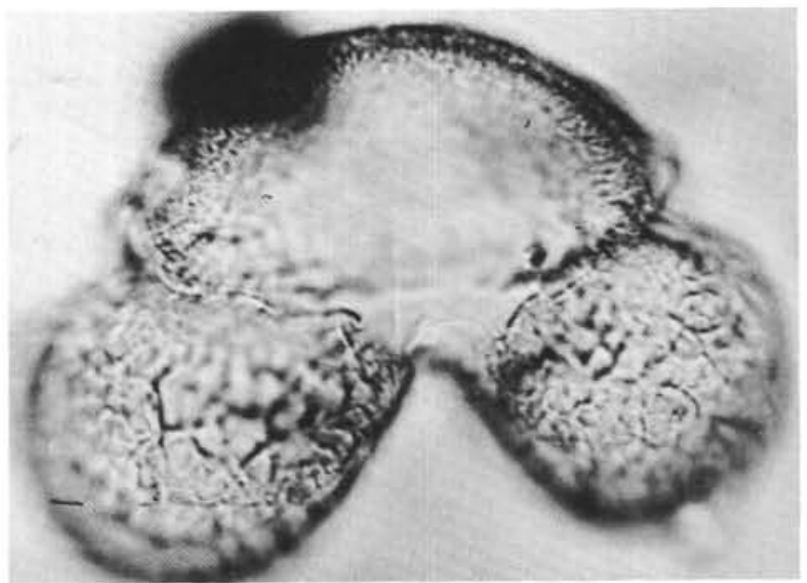

2

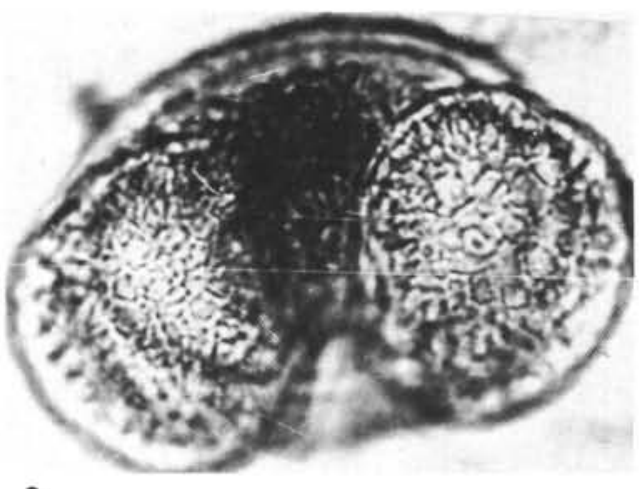

3

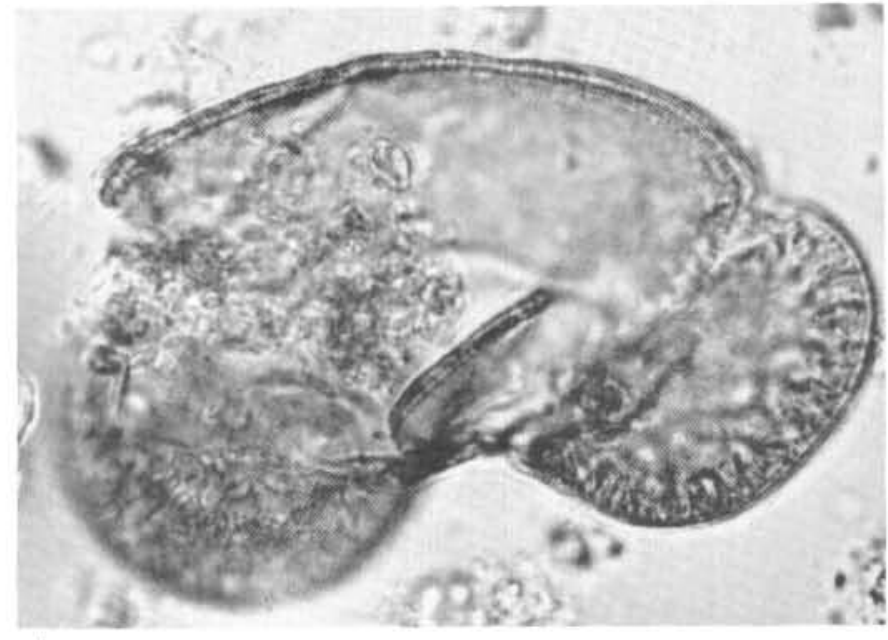

4

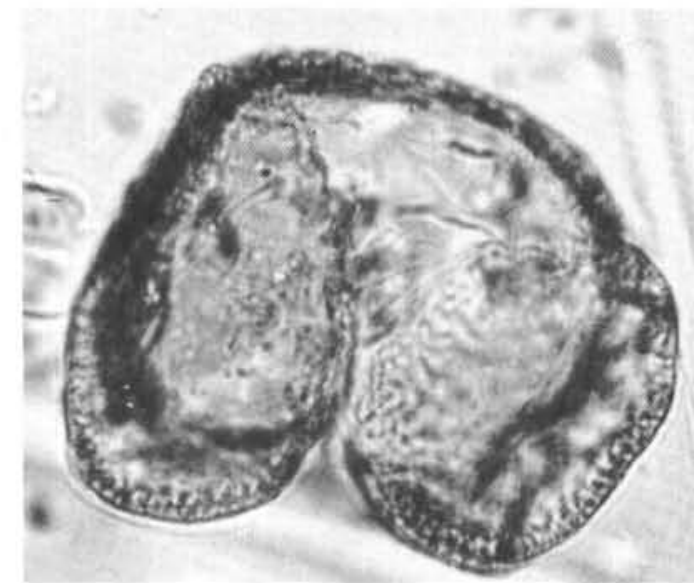

5

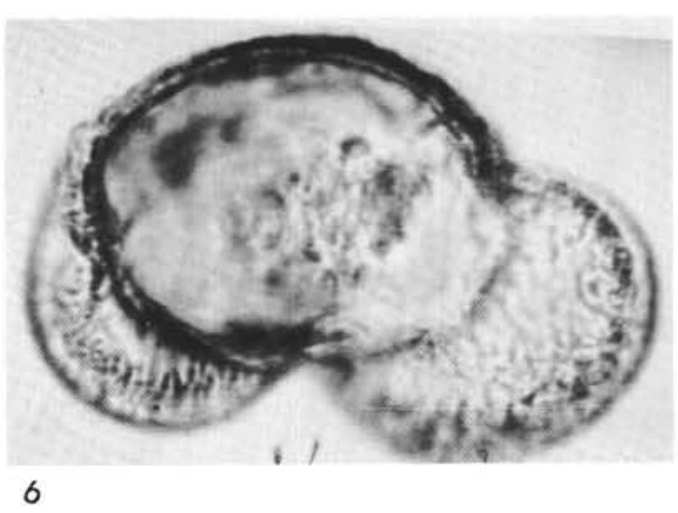




\section{PLATE 4}

(Magnification: all $\times 1000$ )

Figure 1

Figure 2

Figure 3

Figures 4, 5

Figures 6, 7

Figure 8

Figure 9

Figure 10

Figure 11

Figure 12

Figure 13

Figure 14

Figure 15

Figure 16

Figure 17
Tilia sp. Site 345, Sample 6-2, 118-120 cm, Sample No. $561 \mathrm{k} / \mathrm{m}$, Collection No. 3948, Geological Institute of Academy of Sciences USSR, Miocene.

Juglans sp. Site 348, Sample 11-CC, Sample No. 353 k/m, Collection No. 3948, Geological Institute Academy of Sciences USSR, Miocene.

Pterocarya sp. Site 348, Sample 12-CC, Sample No. 354 k/m, Collection No. 3948, Geological Institute of Academy of Sciences USSR, Miocene.

Quercus sp. Site 345, Sample 6-2, 118-120 cm, Sample No. $561 \mathrm{k} / \mathrm{m}$, Collection No. 3948, Geological Institute of Academy of Sciences USSR, Miocene.

Fagus sp. Site 338, Sample 8-3, 40-42 cm, Sample No. $380 \mathrm{k} / \mathrm{m}$, Collection No. 3948, Geological Institute of Academy of Sciences USSR, Miocene.

Betula sp. Site 346, Sample 8-3, 40-42 cm, Sample No. $417 \mathrm{k} / \mathrm{m}$, Collection No. 3948, Geological Institute of Academy of Sciences USSR, Miocene.

Alnus sp.1. Site 345 , Sample 6-2, 118-120 cm, Sample No. $561 \mathrm{k} / \mathrm{m}$, Collection No. 3948, Geological Institute of Academy of Sciences USSR, Miocene.

Alnus sp.2. Site 338, Sample 8-3, 40-42 cm, Sample No. $380 \mathrm{k} / \mathrm{m}$, Collection No. 3948, Geological Institute of Academy of Sciences USSR, Miocene.

Ulmus sp. Site 348, Sample 12, CC, Sample No. 354 k/m, Collection No. 3948, Geological Institute of Academy of Sciences USSR, Miocene.

Tricolpites sp.1. Site 338, Sample 8-3, 40-42 cm. Sample No. 380 $\mathrm{k} / \mathrm{m}$, Collection No. 3948, Geological Institute of Academy of Sciences, USSR, Miocene.

Tricolpites sp.2. Site 338, Sample 8-3, 40-42 cm. Sample No. 380 $\mathrm{k} / \mathrm{m}$, Collection No. 3948, Geological Institute of Academy of Sciences USSR, Miocene.

Ericaceae. Site 338 , Sample 8-3, $40-42 \mathrm{~cm}$. Sample No. $380 \mathrm{k} / \mathrm{m}$, Collection No. 3948, Geological Institute of Academy of Sciences USSR, Miocene.

Tricolporopollenites sp. Site 338, Sample 8-3, 40-42 cm, Sample No. $380 \mathrm{k} / \mathrm{m}$, Collection No. 3948, Geological Institute of Academy of Sciences USSR, Miocene.

Tricolpites sp. Site 338, Sample 8-3, 40-42 cm, Sample No. $380 \mathrm{k} / \mathrm{m}$, Collection No. 3948, Geological Institute of Academy of Sciences USSR, Miocene.

Tricolpites (Quercus) Site 338, Sample 8-3, 40-42 cm, Sample No. $380 \mathrm{k} / \mathrm{m}$, Collection No. 3948, Geological Institute of Academy of Sciences USSR, Miocene. 
PLATE 4

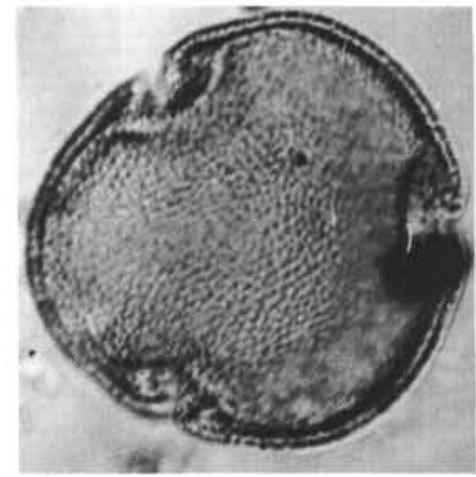

1

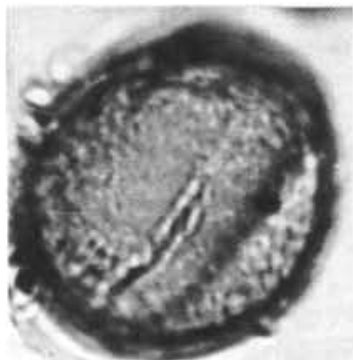

4

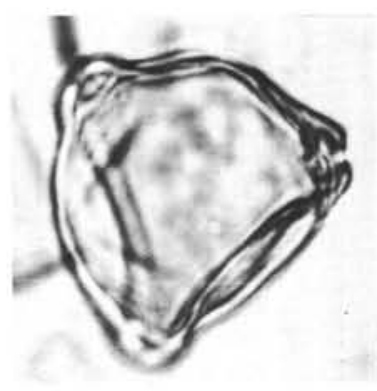

8

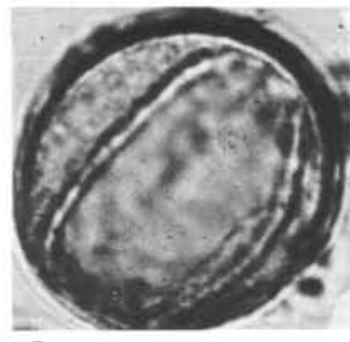

5
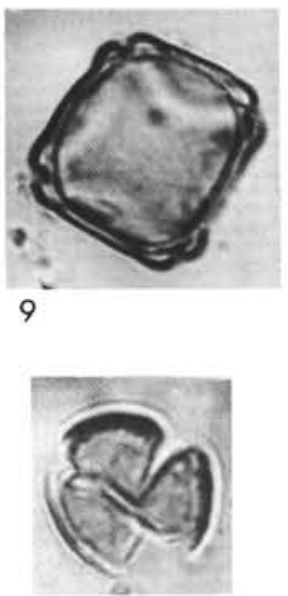

12

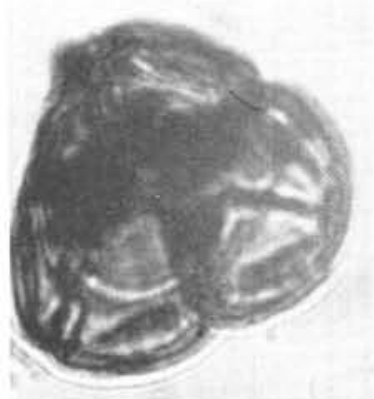

14

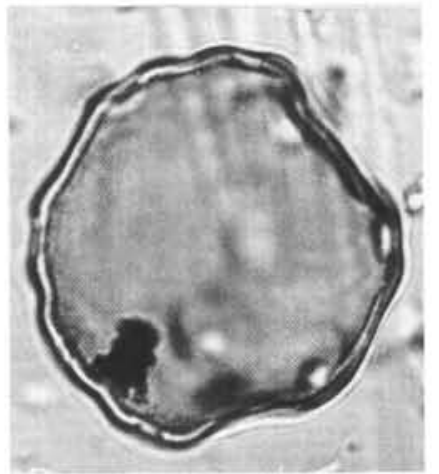

2

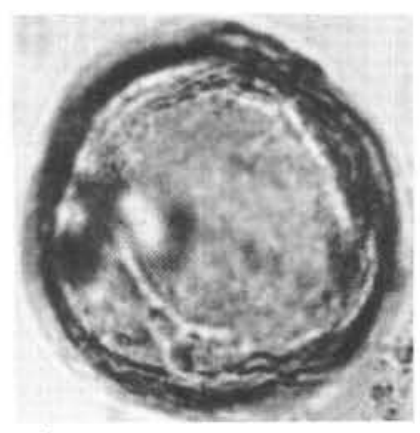

6
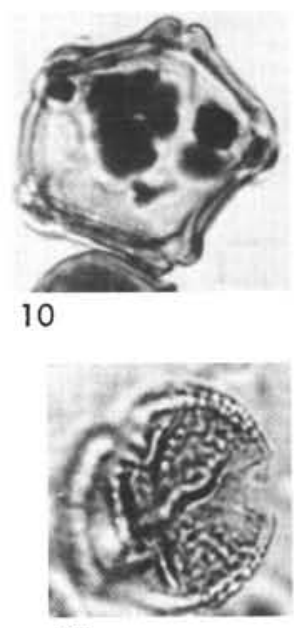

13

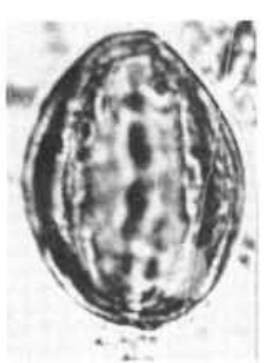

15

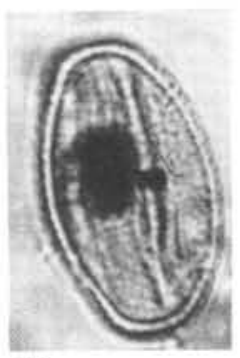

16

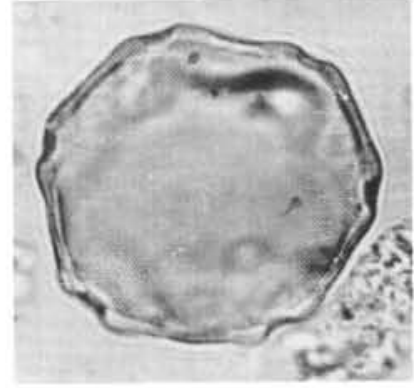

3
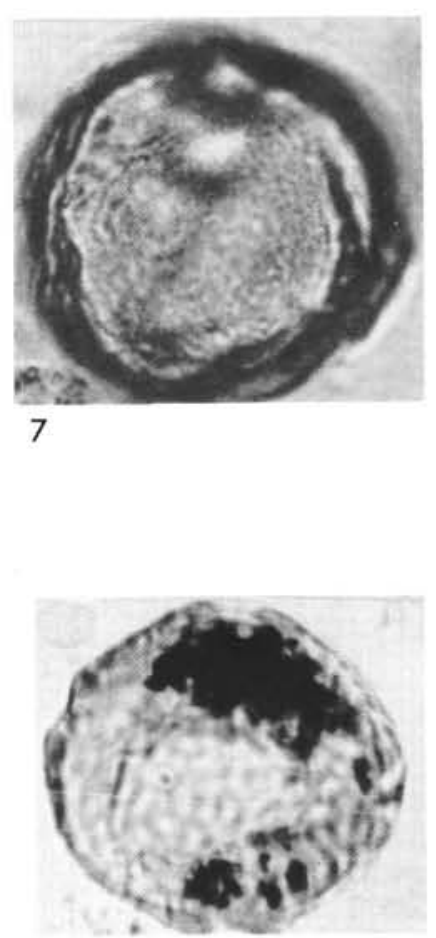

11

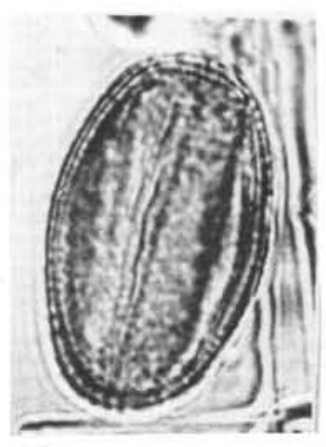

17 


\section{PLATE 5}

(Magnification: all $\times 1000$ )

Figure 1 Cyathea sp. Site 346, Sample 8-2, 80-82 cm, Sample No. 423 k/m, Collection No. 3948 , Geological Institute of Academy of Sciences USSR, Oligocene.

Figure 2 Osmunda sp. 1. Site 346, Sample 10-3, 55-57 cm, Sample No. $428 \mathrm{k} / \mathrm{m}$, Collection No. 3948, Geological Institute of Academy of Sciences USSR, Oligocene.

Figure 3 Lycopodium sp. Site 346, Sample 9-2, 106-108 cm, Sample No. $425 \mathrm{k} / \mathrm{m}$, Collection No. 3948, Geological Institute of Academy of Sciences USSR, Oligocene.

Figure 4 Osmunda sp. 2. Site 346 , Sample $8-2,80-82 \mathrm{~cm}$, Sample No. $423 \mathrm{k} / \mathrm{m}$, Collection No. 3948, Geological Institute of Academy of Sciences USSR, Oligocene.

Figure 5 Polypodiaceae. Site 346, Sample 9-2, 106-108 cm, Sample No. $425 \mathrm{k} / \mathrm{m}$, Collection No. 3948, Geological Institute of Academy of Sciences USSR, Oligocene.

Figure 6 Leiotriletes sp. Site 346, Sample 8-2, 80-82 cm, Sample No. $423 \mathrm{k} / \mathrm{m}$, Collection No. 3948, Geological Institute of Academy of Sciences USSR, Oligocene.

Figure 7 Osmunda sp. Site 346, Sample 9, CC, Sample No. $453 \mathrm{k} / \mathrm{m}$, Collection No. 3948, Geological Institute of Academy of Sciences USSR, Oligocene.

Figure $8 \quad$ Polypodiaceae. Site 346 , Sample $8-2,80-82 \mathrm{~cm}$, Sample No. $423 \mathrm{k} / \mathrm{m}$, Collection No. 3948, Geological Institute of Academy of Sciences USSR, Oligocene.

Figure 9 Leiotriletes $\mathrm{sp}$. Site 346, Sample 10-1, 60-62 cm, Sample No. $427 \mathrm{k} / \mathrm{m}$, Collection No. 3948, Geological Institute of Academy of Sciences USSR, Oligocene.

Figure $10 \quad$ Polypodiaceae, Site 348, Sample 26, CC, Sample No. 367 k/m, Collection No. 3948, Geological Institute of Academy of Sciences USSR, Oligocene.

Figure $11 \quad$ Gleicheniidites $\mathrm{sp}$. Site 338, Sample 14-3, 65-67 cm, Sample No. $385 \mathrm{k} / \mathrm{m}$, Collection No. 3948, Geological Institute of Academy of Sciences USSR, Oligocene.

Figure $12 \quad$ Polypodiaceae. Site 346, Sample 9, CC, Sample No. $453 \mathrm{k} / \mathrm{m}$, Collection No. 3948, Geological Institute of Academy of Sciences USSR, Oligocene.

Figure 13 Sphagnum sp. Site 348, Sample 26, CC, Sample No. $367 \mathrm{k} / \mathrm{m}$, Collection No. 3948, Geological Institute of Academy of Sciences USSR, Oligocene. 


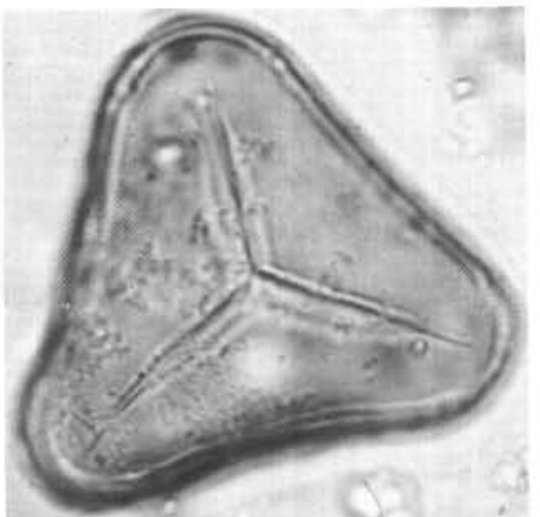

1
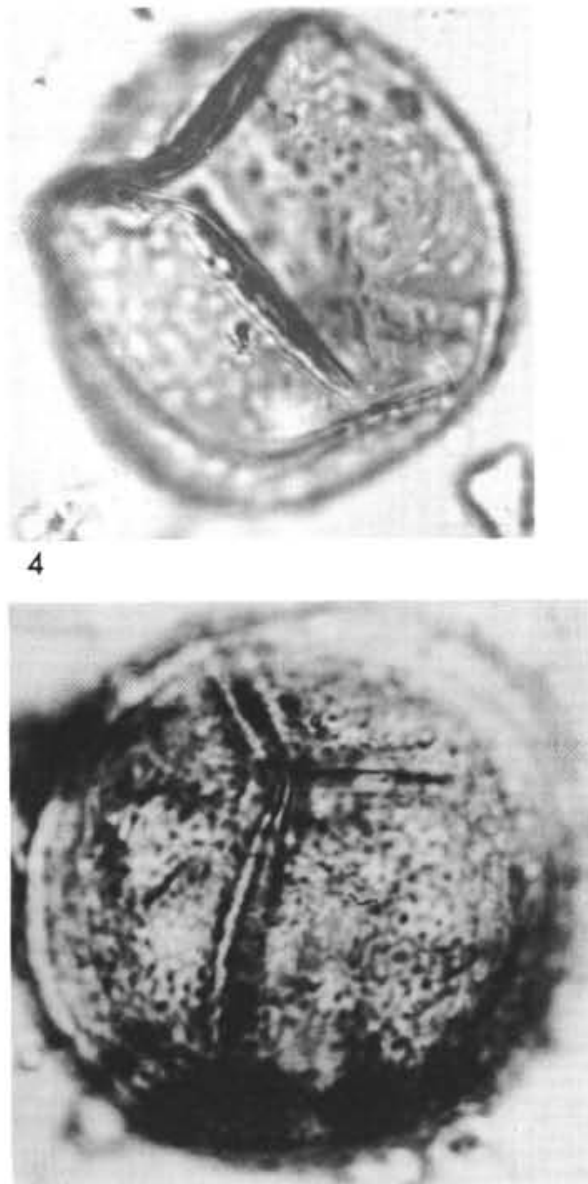

7

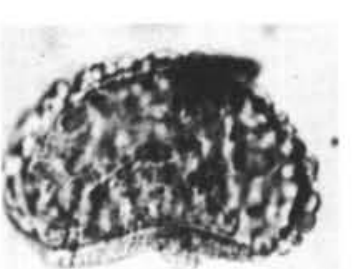

10

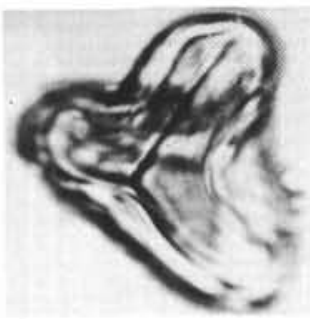

11
PLATE 5

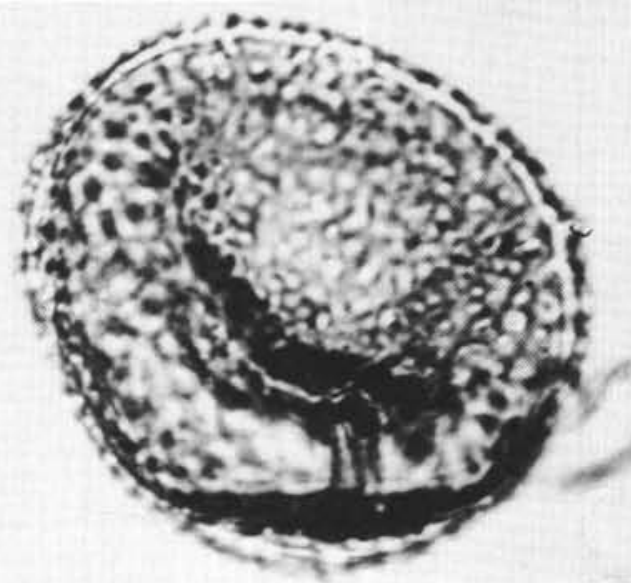

2

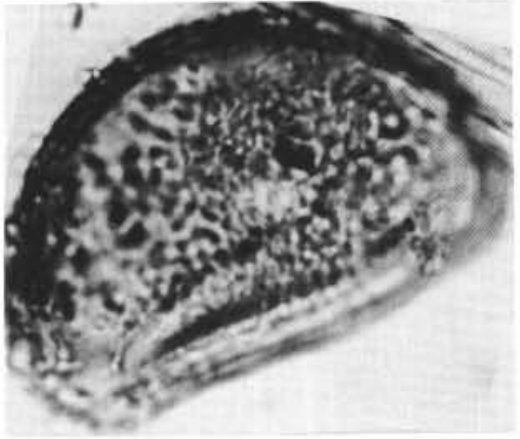

5

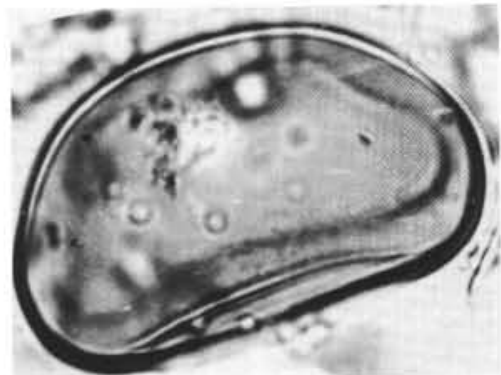

8

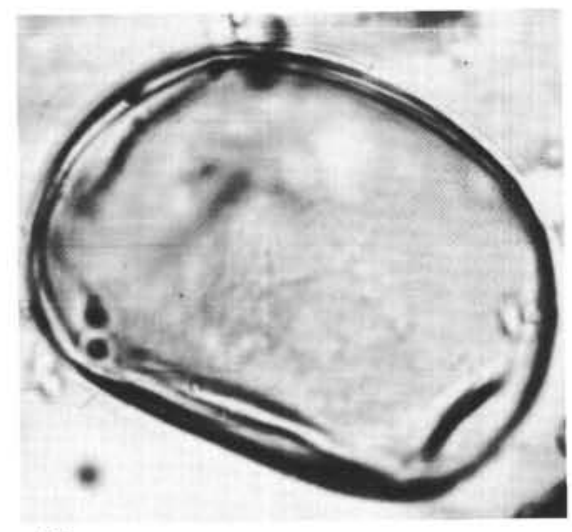

12

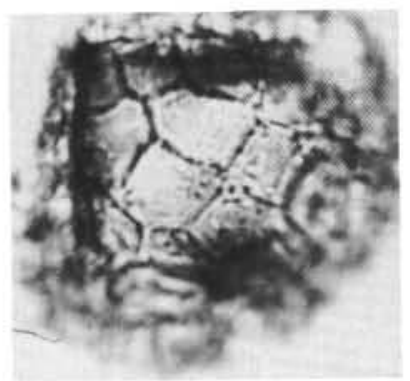

3

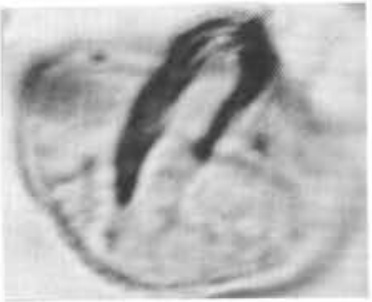

6
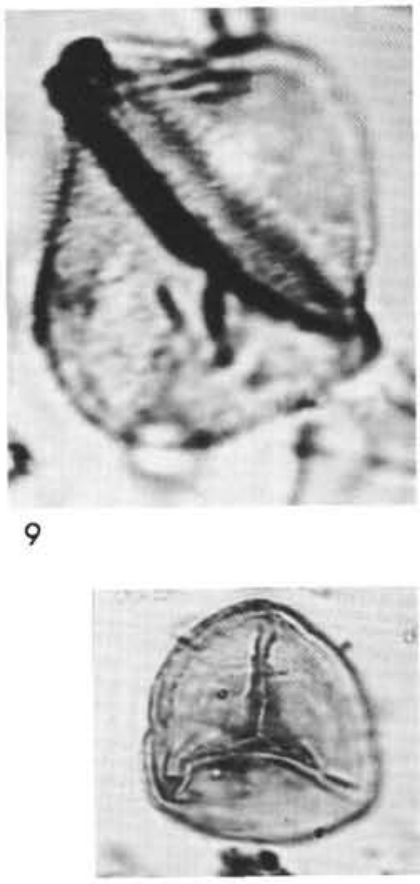

13 


\section{PLATE 6}

(Magnification: all $\times 500$ )

Figure 1

Figure 2

Figure 3

Figure 4

Figure 5

Figure 6

Figure 7

Figure 8

Figure 9

Figure 10

Figure 11

Figure 12

Figure 13
Picea sp. Site 346, Sample 10-3, 55-57 cm, Sample No. 428 k/m, Collection No. 3948, Geological Institute of Academy of Sciences USSR, Oligocene.

Tsuga krutzschii Sivak. Site 338, Sample 19-3, 60$62 \mathrm{~cm}$, Sample No. 388 k/m, Collection No. 3948, Geological Institute of Academy of Sciences USSR, Oligocene.

Tsuga cf. diversifolia. Site 346, Sample 10-3, 55-57 $\mathrm{cm}$, Sample No. $428 \mathrm{k} / \mathrm{m}$, Collection No. 3948, Geological Institute of Academy of Sciences USSR, Oligocene.

Picea sp. Site 346, Sample 9-2, 106-108 cm, Sample No. $425 \mathrm{k} / \mathrm{m}$, Collection No. 3948, Academy of Sciences USSR, Oligocene.

Tsuga sp. Site 246, Sample 9-2, 106-108 cm, Sample No. 425 k/m, Collection No. 3948, Geological Institute of Academy of Sciences USSR, Oligocene.

Tsuga sp. Site 346, Sample 10-3, 55-57 cm, Sample No. $428 \mathrm{k} / \mathrm{m}$, Collection No. 3948, Geological Institute of Academy of Sciences USSR, Oligocene.

Keteleeria sp. Site 346, Sample 11-2, 100-102 cm, Sample No. 429 k/m, Collection No. 3948, Geological Institute of Academy of Sciences USSR, Oligocene.

Abies sp. Site 346, Sample 8-2, 80-82 cm, Sample No. 423 k/m, Collection No. 3948, Geological Institute of Academy of Sciences USSR, Oligocene.

Pinus sibiricaeformis Zakl. Site 346, Sample 6-4, 60-62 cm, Sample No. $420 \mathrm{k} / \mathrm{m}$, Collection No. 3948, Geological Institute of Academy of Sciences USSR, Oligocene.

Pinus sect. Strobus. Site 346, Sample 9-2, 106-108 $\mathrm{cm}$, Sample No. $425 \mathrm{k} / \mathrm{m}$, Collection No. 3948, Geological Institute of Academy of Sciences USSR, Oligocene.

Pinus ponderosseformis Zakl. Site 346, Sample 7-1, 90-92 cm, Sample No. $42 \mathrm{k} / \mathrm{m}$, Collection No. 3948, Geological Institute of Academy of Sciences USSR, Oligocene.

Pinus sect. banksianaeformis Zakl. Site 338, Sample 19-3, 60-62 cm, Sample No. 388 k/m, Collection No. 3948, Geological Institute of Academy of Sciences USSR, Oligocene.

Cedrus pusilla Zakl. Site 346, Sample 6-4, 60-62 $\mathrm{cm}$, Sample No. $420 \mathrm{k} / \mathrm{m}$, Collection No. 3948, Geological Institute of Academy of Sciences USSR, Oligocene. 
PLATE 6

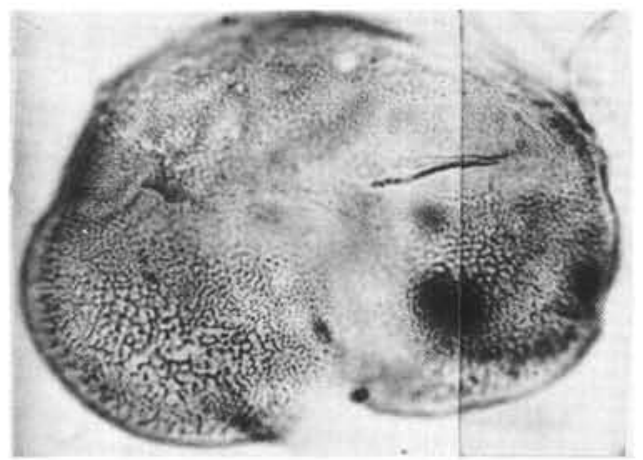

1

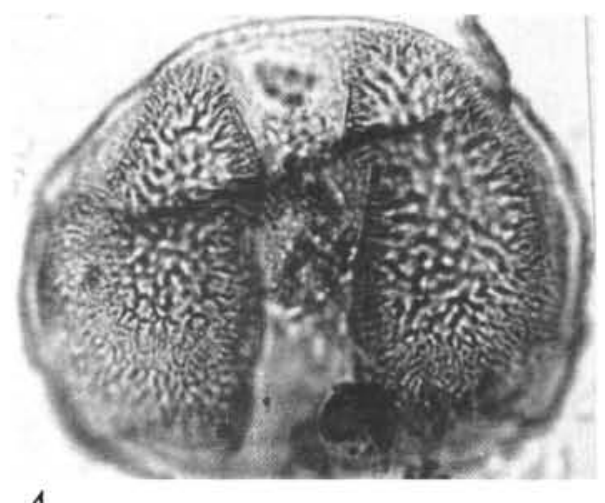

4
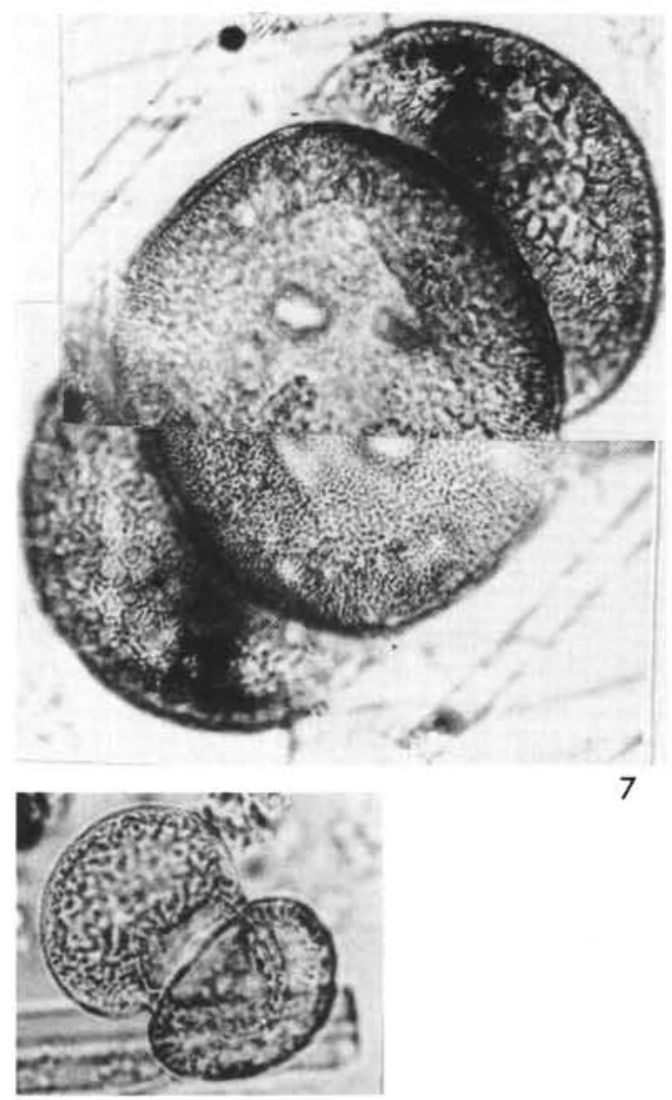

12

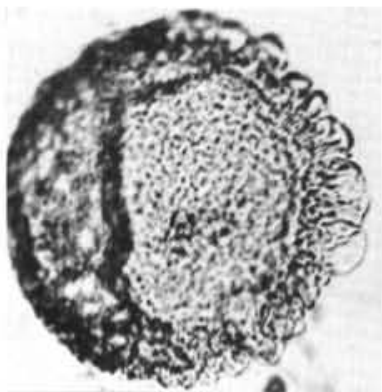

2

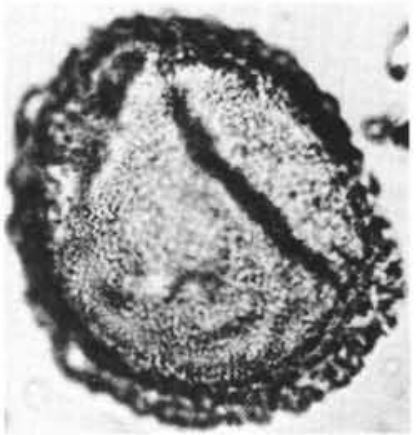

5
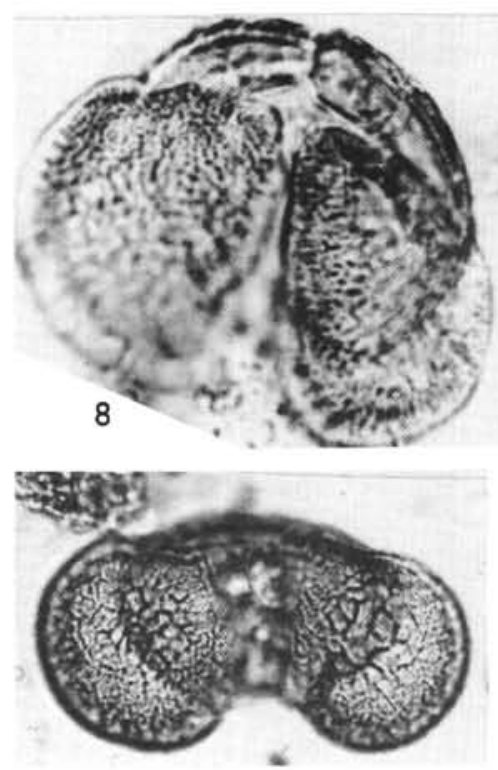

10

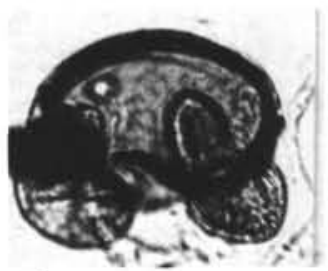

13

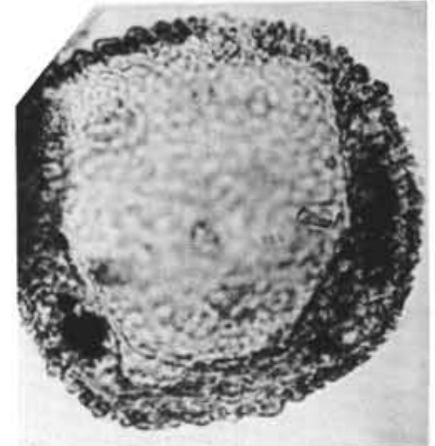

3

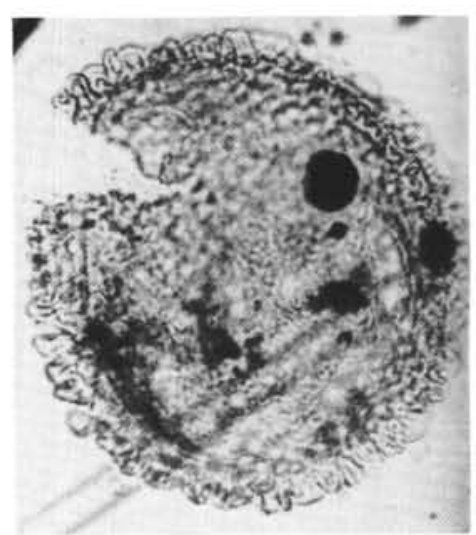

6
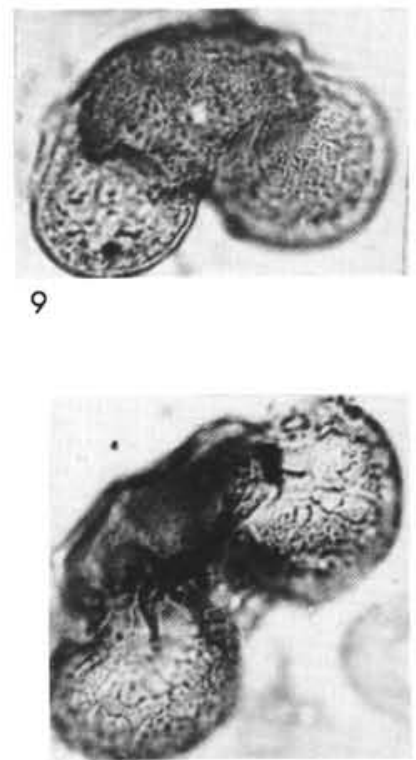

11 


\section{PLATE 7}

Figure 1 Tsuga cf. diversifolia. Site 346, Sample 11-2, 100$104 \mathrm{~cm}$, Sample No. $429 \mathrm{k} / \mathrm{m}$, Collection No. 3948, Geological Institute of Academy of Sciences USSR, Oligocene.

Figure 2 Cedrus sp. Site 348, Sample 26, CC, Sample No. $367 \mathrm{k} / \mathrm{m}$, Collection No. 3948, Geological Institute of Academy of Sciences USSR, Oligocene.

Figure 3 Pinus sibiricaeformis Zakl. Site 346, Sample 9-5, 60-62 cm, Sample No. $426 \mathrm{k} / \mathrm{m}$, Collection No. 3948, Geological Institute of Academy of Sciences USSR, Oligocene.

Figure 4 Pinus sect., Banksia. Site 336, Sample 15, CC, Sample No. $591 \mathrm{k} / \mathrm{m}$, Collection No. 3948, Geological Institute of Academy of Sciences USSR, Oligocene.

Figure 5 Pinus sp. Site 346, Sample 8-2, 80-82 cm, Sample No. $423 \mathrm{k} / \mathrm{m}$, Collection No. 3948, Geological Institute of Academy of Sciences USSR, Oligocene.

Figure 6 Taxodium sp. Site 336, Sample 18, CC, Sample No. 586, Collection No. 3948, Geological Institute of Academy of Sciences USSR, Oligocene.

Figure 7 Sequoia $\mathrm{sp}$. Site 338, Sample 8-3, 40-42 cm, Sample No. $380 \mathrm{k} / \mathrm{m}$, Collection No. 3948 , Geological Institute of Academy of Sciences USSR, Oligocene.

Figure 8 Taxodium sp. Site 338, Sample 13-6, 60-62 cm, Sample No. $383 \mathrm{k} / \mathrm{m}$, Collection No. 3948, Geological Institute of Academy of Sciences USSR, Oligocene.

Figure 9 Pinus protocembrae Zakl. Site 346, Sample 9-5, 60$62 \mathrm{~cm}$, Sample No. 426, Collection No. 3948, Geological Institute of Academy of Sciences USSR, Oligocene. 


\section{PLATE 7}
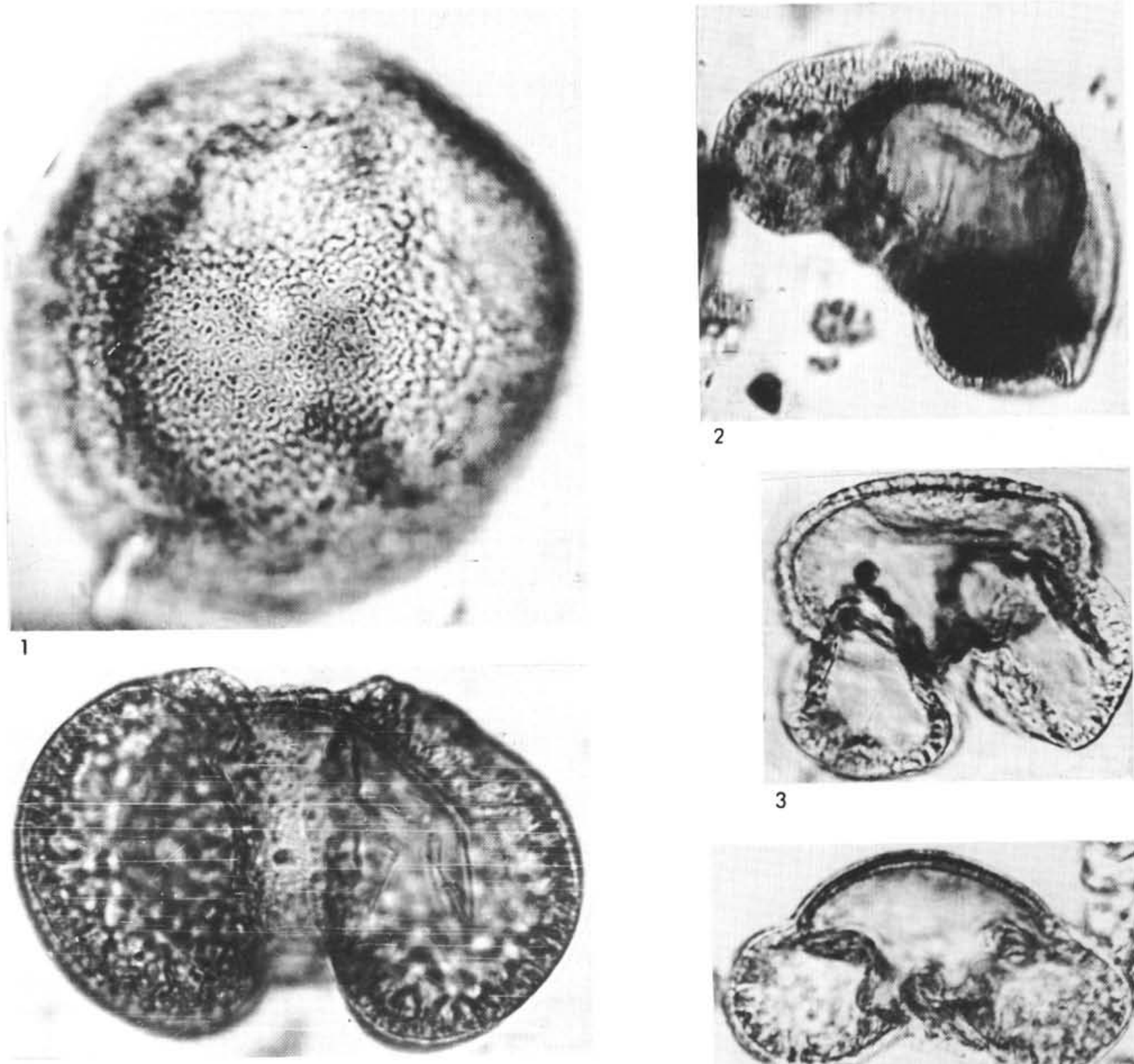

4

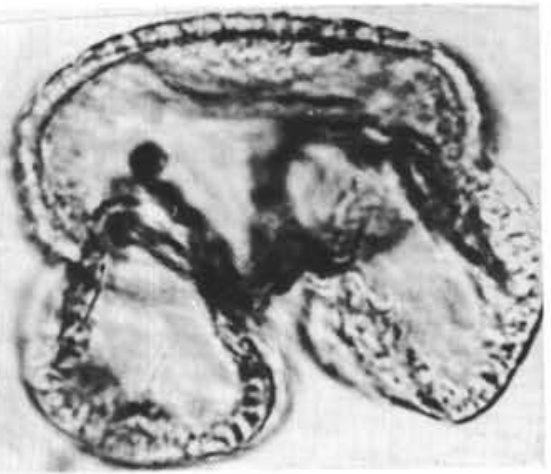

3

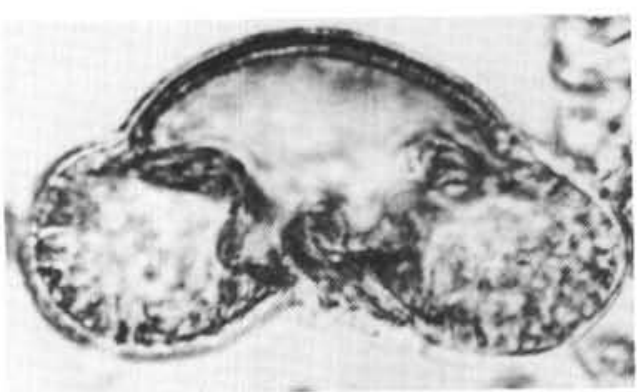

5
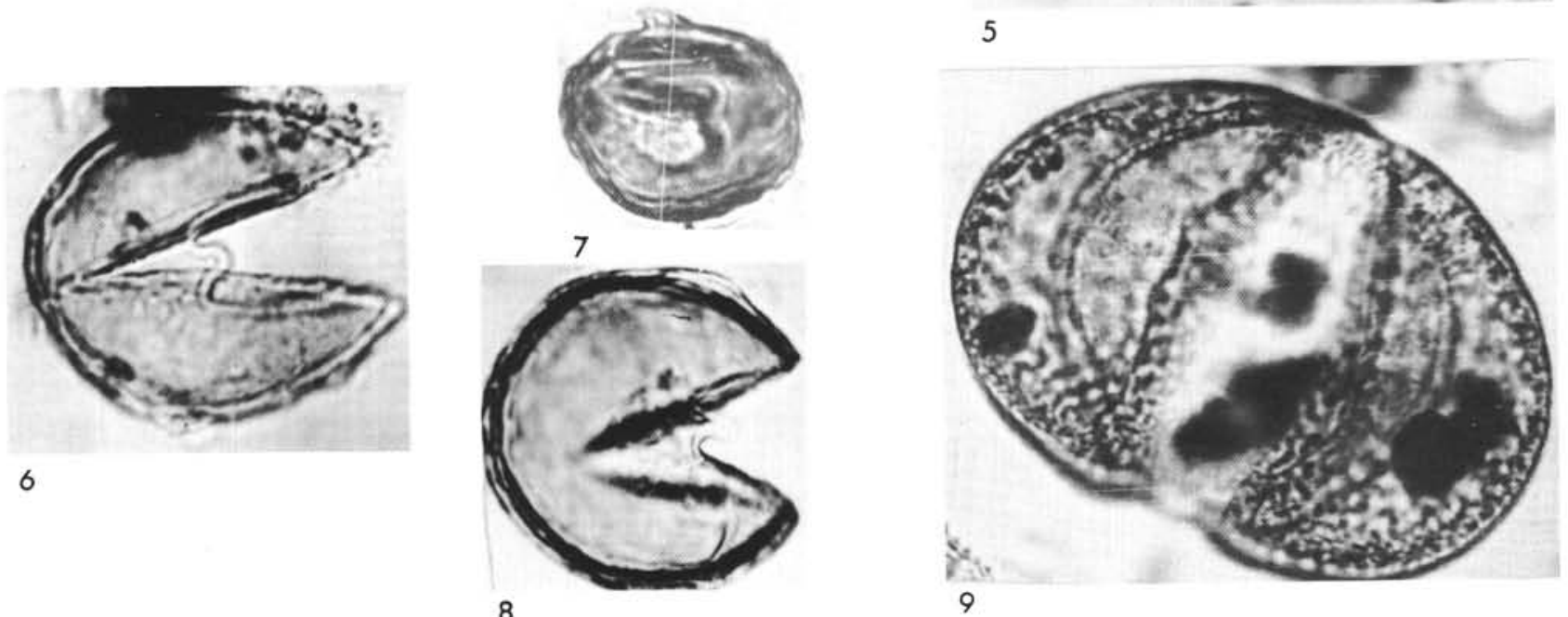


\section{PLATE 8}

Figure 1

Figure 2

Figure 3

Figure 4

Figure 5

Figure 6

Figure 7

Figure 8

Figure 9

Figure 10

Figure 11

Figure 12

Figure 13

Figure 14

Figure 15

Figure 16

Figure 17

Figure 18

Figure 19

Figure 20
Cyclocarya sp. Site 336, Sample 18-3, 78-81 cm, Sample No. 585 k/m, Collection No. 3948, Geological Institute of Academy of Sciences USSR, Oligocene.

Juglana sp. Site 338, Sample 18, CC, Sample No. 586 k/m, Collection No. 3948, Geological Institute of Academy of Sciences USSR, Oligocene.

Myrica sp. Site 346, Sample 8-2, 80-82 cm, Sample No. $423 \mathrm{k} / \mathrm{m}$, Collection No. 3948 , Geological Institute of Academy of Sciences USSR, Oligocene.

Myrica sp. Site 348, Sample 26, CC, Sample No. 367 k/m, Collection No. 3948, Geological Institute of Academy of Sciences USSR, Oligocene.

Betula sp. Site 336, Sample 23-3, 60-62 cm, Sample No. $347 \mathrm{k} / \mathrm{m}$, Collection No. 3948, Geological Institute of Academy of Sciences USSR, Oligocene.

Myrica sp. Site 346, Sample 6-2, 90-92 cm, Sample No. 419, Collection No. 3948, Geological Institute of Academy of Sciences USSR, Oligocene.

Betula sp. Site 346, Sample 6-2, 90-92 cm, Sample No. 419 k/m, Collection No. 3948, Geological Institute of Academy of Sciences USSR, Oligocene.

Comptonia sp. Site 336, Sample 15, CC, Sample No. 591 k/m, Collection No. 3948, Geological Institute of Academy of Sciences USSR, Oligocene.

Alnus sp. Site 345, Sample 6-2, 118-120 cm, Sample No. 561 k/m, Collection No. 3948, Geological Institute of Academy of Sciences USSR, Oligocene.

Engelhardtia sp., Site 346, Sample 9, CC, Sample No. 453 k/m, Collection No. 3948, Geological Institute of Academy of Sciences USSR, Oligocene.

Engelhardtia sp. Site 346, Sample 9, CC, Sample No. 453 k/m, Collection No. 3948, Geological Institute of Academy of Sciences USSR, Oligocene.

Castanea sp. Site 346, Sample 9-5, 60-62 cm, Sample No. 426 k/m, Collection No. 3948, Geological Institute of Academy of Sciences USSR, Oligocene.

Ericaceae. Site 346, Sample 9, CC, Sample No. 453 k/m, Collection No. 3948, Geological Institute of Academy of Sciences USSR, Oligocene.

Ericaceae. Site 346, Sample 9, CC, Sample No. 453 k/m, Collection No. 3948, Geological Institute of Academy of Sciences USSR, Oligocene.

Ericaceae. Site 346, Sample 8-2, 80-82 cm, Sample No. $423 \mathrm{k} / \mathrm{m}$, Collection No. 3948, Geological Institute of Academy of Sciences USSR, Oligocene.

Tricolpites sp. Site 338, Sample 18, CC, Sample No. 586 k/m, Collection No. 3948, Geological Institute of Academy of Sciences USSR, Oligocene.

Tricolpites sp. Site 338, Sample 22-3, 54-56 cm, Sample No. $391 \mathrm{k} / \mathrm{m}$, Collection No. 3948, Geological Institute of Academy of Sciences USSR, Oligocene.

Tricolporopollenites sp. Site 338, Sample 18, CC, Sample No. 586 k/m, Collection No. 3948, Geological Institute of Academy of Sciences USSR, Oligocene.

Tricolporopollenites $\mathrm{sp}$. Site 338, Sample 19-3, 30-32 cm, Sample No. 388 k/m, Collection No. 3948, Geological Institute of Academy of Sciences USSR, Oligocene.

Angiospermae. Site 348, Sample 26, CC, Sample No. 367 k/m, Collection No. 3948, Geological Institute of Academy of Sciences USSR, Oligocene. 
PLATE 8

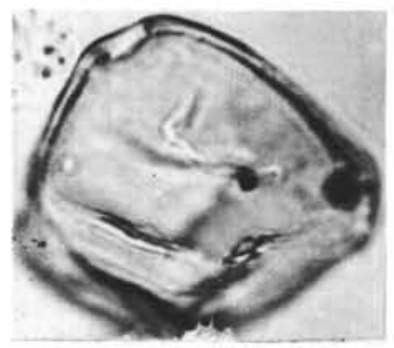

1

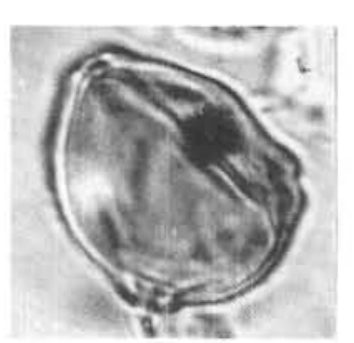

5
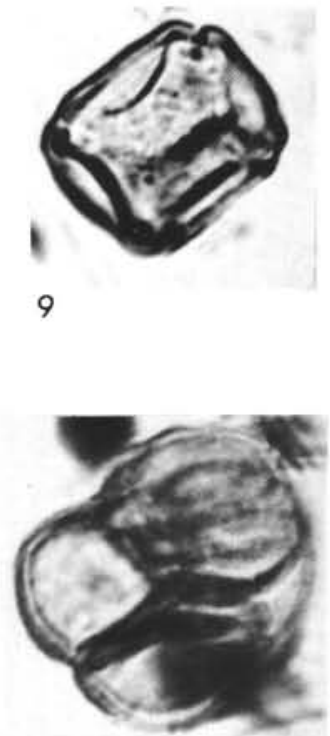

13

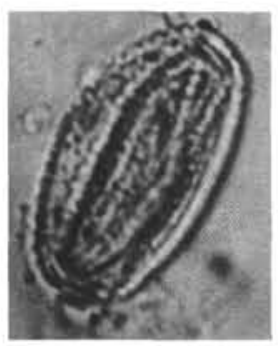

17

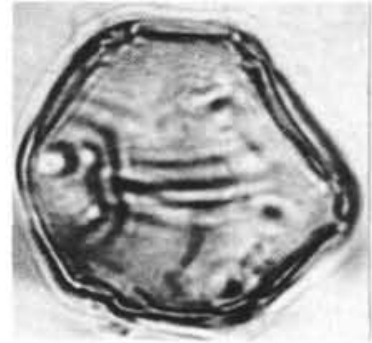

2
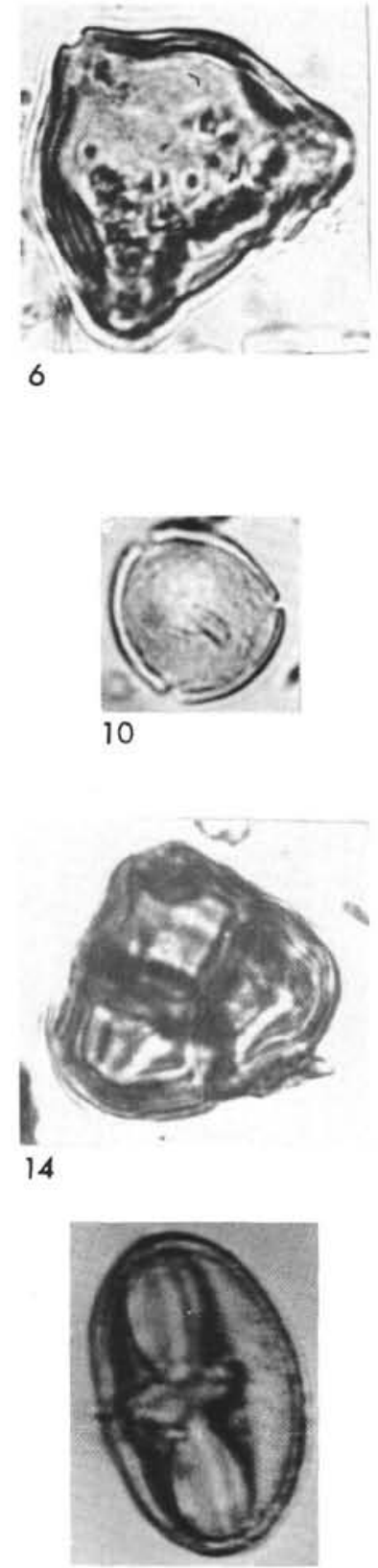

18

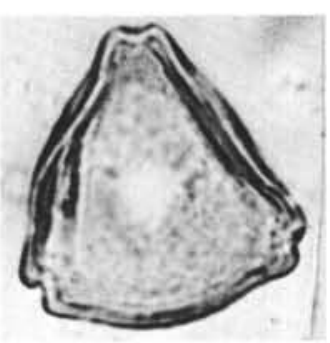

3
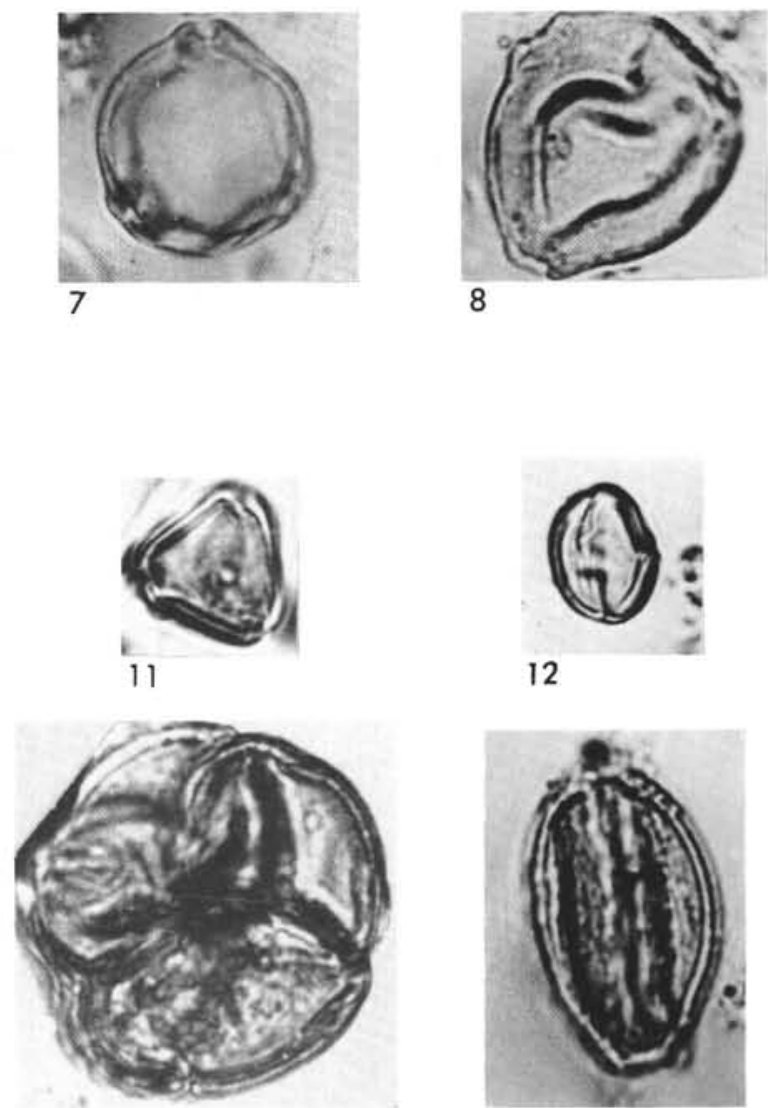

15

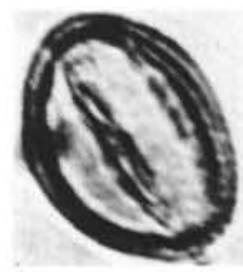

19

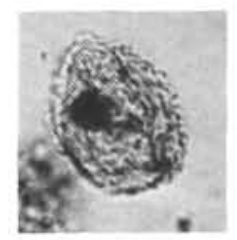




\section{PLATE 9}

Figure 1 Leiotriletes adriensis W. Kr. Site 346, Sample 14-2, 103-107 cm, Sample No. 435 k/m, Eocene.

Figure $2 \quad$ Stereisporites minor Roatz, W. Kr. Site 346, Sample 19-2, 33-35 cm, Sample No. $443 \mathrm{k} / \mathrm{m}$, Eocene.

Figures 3,4 Retitrisporites pseudoclavatus W. Kr. Site 346, Sample 18-3, 80-82 cm, Sample No. $442 \mathrm{k} / \mathrm{m}$, Eocene.

Figure $5 \quad$ Cedrus laxireticulatus Zakl. Site 346, Sample 20-1, 123-125 cm, Sample No. 444 k/m, Eocene.

Figure $6 \quad$ Triporopollenites grandis Kedv. Site 346, Sample 19-2, 33-35 cm, Sample No. $443 \mathrm{k} / \mathrm{m}$, Eocene.

Figure $7 \quad$ Complexipollis sp. Site 346, Sample 14-2, 105-107 $\mathrm{cm}$, Sample No. $435 \mathrm{k} / \mathrm{m}$, Eocene.

Figure 8 Sporopollis singularis Zakl. Site 346, Sample 18-1, 62-64 cm, Sample No. $441 \mathrm{k} / \mathrm{m}$, Eocene.

Figure 9 Triatriopollenites rorubituites Pfl. Site 346, Sample 18-1, 62-64 cm, Sample No. $441 \mathrm{k} / \mathrm{m}$, Eocene.

Figure 10 Interpollis supplingensis W. Kr. Site 346, Sample 20-1, 123-125 cm, Sample No. 444 k/m, Eocene.

Figure 11 Alnipollenites verus $\mathrm{R}$. Pot. Site 346, Sample 20-1, 33-35 cm, Sample No. 443 k/m, Eocene.

Figure 12 Aquilapollenites subtilis Samoil. Site 346, Sample 12-3, 114-116 cm, Sample No. 448 k/m, Eocene.

Figure 13 Triprojectus sp. Site 346, Sample 14-2, 103-107 cm, Sample No. $435 \mathrm{k} / \mathrm{m}$, Eocene.

Figure 14 Trudopollis sp. Site 346, Sample 13-3, 114-116 cm, Sample No. $434 \mathrm{k} / \mathrm{m}$, Eocene.

Figure 15 Anacolosidites supplingensis W. Kr. Site 346, Sample 14-2, $105-107 \mathrm{~cm}$, Sample No. $435 \mathrm{k} / \mathrm{m}$, Eocene.

Figure 16 Engelhardtia sp. Site 346, Sample 20-1, 123-125 $\mathrm{cm}$, Sample No. $444 \mathrm{k} / \mathrm{m}$, Eocene. 
PLATE 9

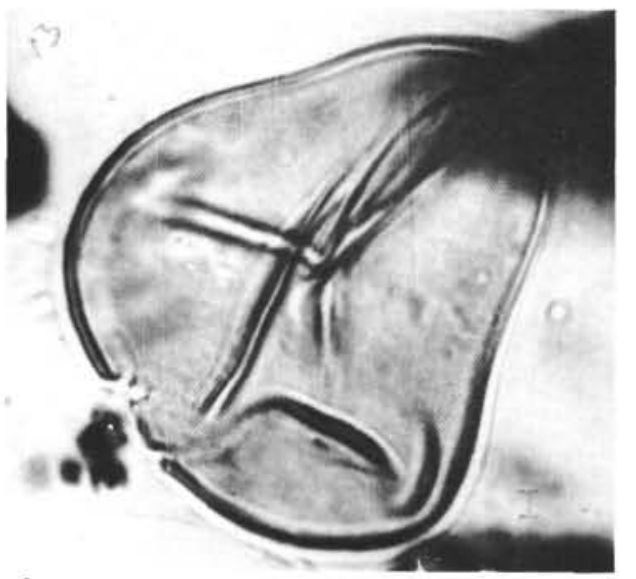

1

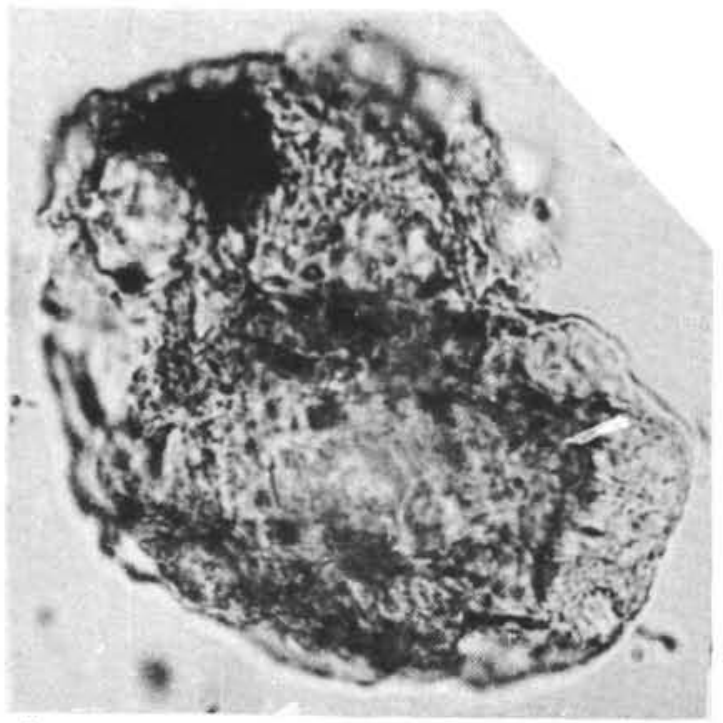

5
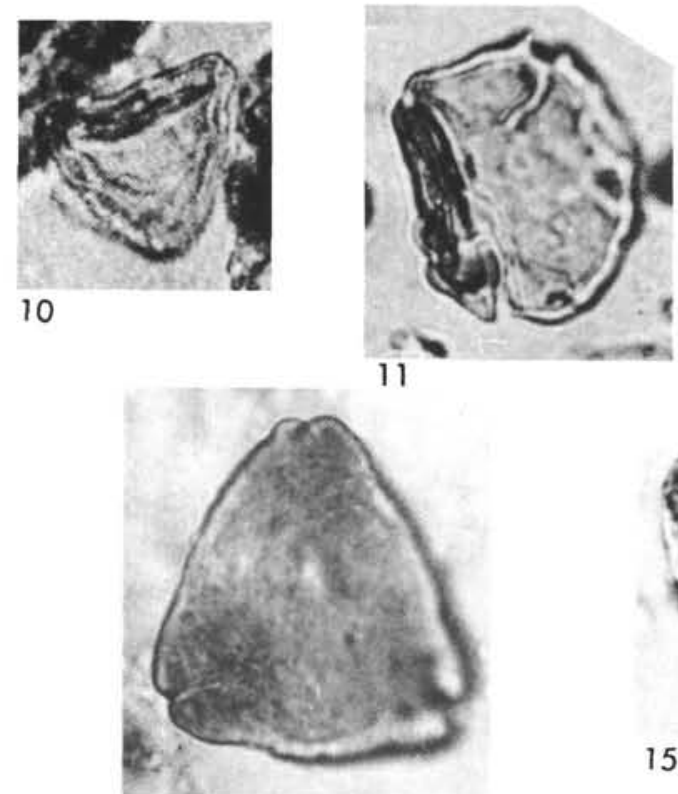

12

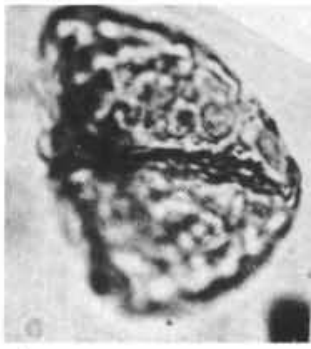

4
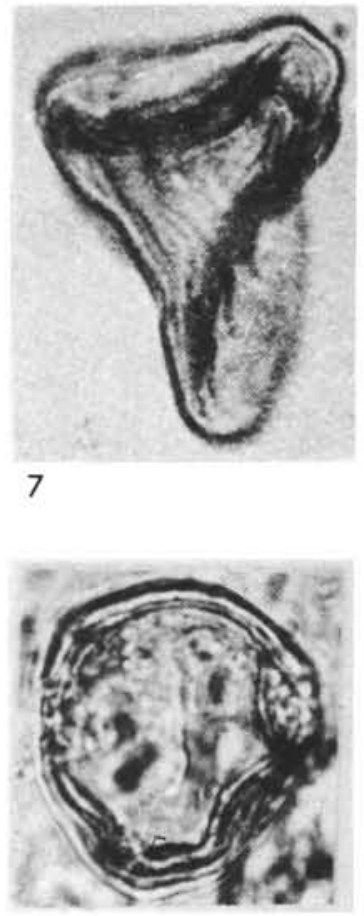

9
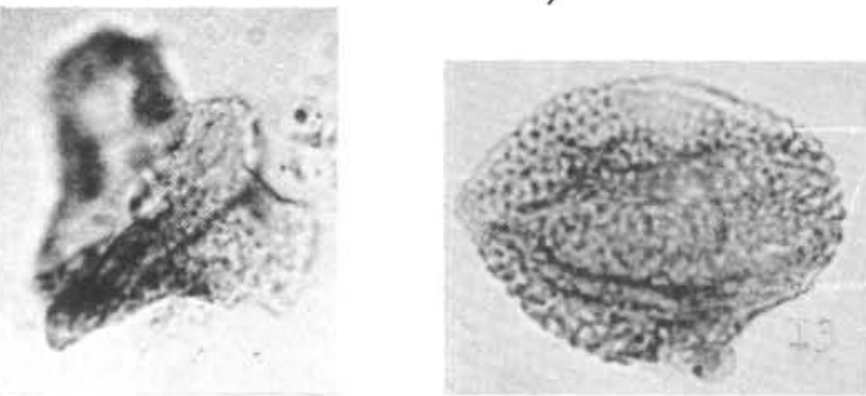

13
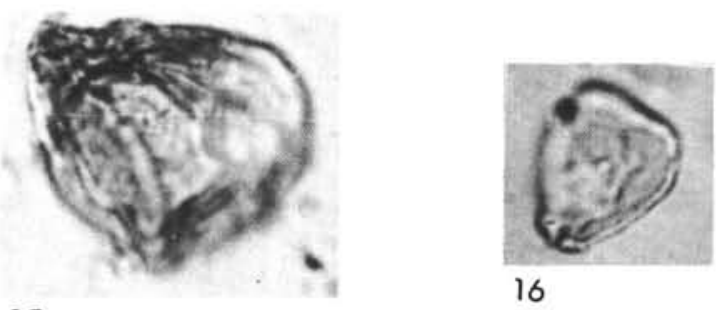